\title{
Three Supreme Court "Failures" and a Story of Supreme Court Success
}

\author{
Corinna Barrett Lain*
}

Plessy v. Ferguson. Buck v. Bell. Korematsu v. United States. Together, these three decisions legitimated 'separate but equal,' sanctioned the forced sterilization of thousands, and ratified the removal of Japanese Americans from their homes during World War II. By Erwin Chemerinsky's measure in The Case Against the Supreme Court, all three are Supreme Court failures-cases in which the Court should have protected vulnerable minorities, but failed to do so. Considered in historical context, however, a dramatically different impression of these cases, and the Supreme Court that decided them, emerges. In two of the cases-Plessy and Buck-the Court's ruling reflected the progressive view at the time, and in the thirdKorematsu-the extralegal context of the case was strong enough to draw the support of Justices Black and Douglas, two of the Court's most staunch civil liberties defenders. Plessy, Buck, and Korematsu are potent reminders of the need to historically situate the Supreme Court when evaluating its proclivity to protect. But this is not to say that an ahistoric view of the Court's protective capacity is all bad. However historically inaccurate, the Supreme Court's image as a countermajoritarian protector also has a curious upside, setting in motion forces that can, over time, enable and inspire the Court's protection. In the end, our expectations of the Supreme Court as a countermajoritarian hero both give rise to a rhetoric of failure and pave the way for future protection. What is vastly underappreciated is the connection between the two-how within the rhetoric of failure lies a larger, and largely untold, story of Supreme Court success.

\footnotetext{
* Professor of Law and Associate Dean of Faculty Development, University of Richmond School of Law. Thanks to the faculty of Vanderbilt Law School, particularly Suzanna Sherry, for the insightful comments and questions I received while workshopping this piece there. Special thanks to Eric Berger, Jud Campbell, Jessica Erickson, Jim Gibson, Meredith Harbach, Paul Lombardo, Shari Motro, Abigail Perdue, Wendy Perdue, Allison Tait, Mary Kelly Tate, and Adrian Vermeule for comments on earlier drafts, and to Dan Hogan, Zack McDonald, and Holly Wilson for their excellent research assistance.
} 
INTRODUCTION 1020

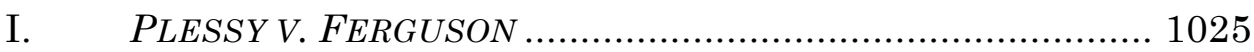

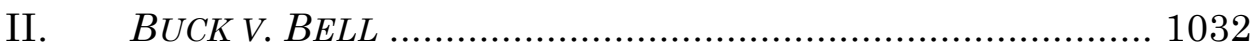

III. KOREMATSU V. UNITED STATES ................................. 1044

IV. WHAT TO MAKE OF THREE

SUPREME COURT "FAILURES" ....................................... 1058

A. $\quad$ Historical Context Matters ............................... 1059

B. Three Ways Culture Can Constrain the Supreme

Court's Proclivity to Protect................................ 1064

C. $\quad$ Story of Supreme Court Success........................ 1067

CONCLUSION.......................................................................... 1074

\section{INTRODUCTION}

"[T]he Supreme Court is not the institution that I once revered," writes Erwin Chemerinsky in The Case Against the Supreme Court-a provocative, important work that also happens to be a great read. ${ }^{1}$ Chemerinsky's claim is that the Supreme Court ought to be protecting vulnerable minorities from repressive majorities, but it has not done so. " "The Court has frequently failed, throughout American history, at its most important tasks, at its most important moments," he argues. ${ }^{3}$ This is Chemerinsky's case against the Supreme Court, and it is a sweeping indictment.

Of the cases Chemerinsky cites to prove his point, three stand out as particularly strong examples of the Supreme Court's failure to protect: Plessy v. Ferguson, ${ }^{4}$ Buck v. Bell, ${ }^{5}$ and Korematsu v. United States. ${ }^{6}$ Plessy is the 1896 decision that upheld 'separate but equal'

1. ERwin Chemerinsky, The CASE Against The Supreme Court 5 (2014).

2. Id. at 10:

I believe that the two preeminent purposes of the Court are to protect the rights of minorities who cannot rely on the political process and to uphold the Constitution in the face of any repressive desires of political majorities. . . My thesis, developed in the chapters of this book, is that the Court has largely failed at both of these tasks.

For an argument that the very fact of Chemerinsky's claim is evidence of a larger story of Supreme Court success, see infra Part III.C.

3. Id. at 5 .

4. 163 U.S. 537 (1896).

5. 274 U.S. 200 (1927).

6. 323 U.S. 214 (1944). I passed by Dred Scott v. Sanford, 60 U.S. (19 How.) 393 (1857) (holding that African Americans, whether enslaved or free, could not be citizens and that Congress lacked the power to ban slavery in U.S. territories), for the same reason that others have left it off the Supreme Court's "worst of the worst" list. See BARRY FRIEDMAN, THE WILL OF THE PEOPLE 372 (2009) ("Many today would pick Dred Scott as the Court's greatest gaffe, but at 
racial classifications. ${ }^{7}$ Buck is the 1927 decision that upheld involuntary sterilization of the hereditarily "feebleminded." 8 And Korematsu is the 1944 decision that upheld the removal of Japanese Americans from their homes during World War II. ${ }^{9}$ All three make the short list of most maligned cases in Supreme Court history, cases uniformly condemned as moral failures, or at least instances in which the Court let us down. ${ }^{10}$ Indeed, Plessy and Korematsu are considered so odious that they have earned the dubious distinction of "anticanon," 11 and Buck is considered so grossly misguided that Chemerinsky chose it as the opening vignette of his book. ${ }^{12}$ By Chemerinsky's measure, all three are compelling examples of Supreme Court failures-cases in which the Court should have protected vulnerable minorities, but failed to do so.

Considered in historical context, however, a dramatically different impression of these cases, and the Supreme Court that decided them, comes into view. In two of the three cases-Plessy and Buck - the Court's decision reflected the progressive view at the time, and in the third-Korematsu-the historical context was strong enough to draw the support of Justices Douglas and Black, two of the Court's most staunch civil liberties defenders. In all three cases, reconstructing the historical context in which the Justices were operating leads to an important insight: it would have been wildly

least in that case the justices thought they were standing up for minority rights, albeit the property rights of slaveholders."); see also MARK A. GRABER, DRED SCOTT AND THE PROBLEM OF Constitutional Evil 1, 4 (2006) ("My claim is that the result in Dred Scott v. Sanford may have been constitutionally correct. . . . Careful historical analysis belies the standard institutional, historical, and aspirational criticisms of that decision.").

7. See Plessy, 163 U.S. at 550-51.

8. See Buck, 274 U.S. at 207.

9. See Korematsu, 323 U.S. at 224 .

10. See Adam Cohen, Imbeciles 9-10 (2016) (discussing "the Supreme Court's worst decisions" and naming Plessy, Buck, and Korematsu as three of the five cases on that list); Suzanna Sherry, Why We Need More Judicial Activism, in Constitutionalism, Executive Power, AND the SPIRIT of Moderation (Giorgi Areshidze, Paul Carrese, \& Suzanna Sherry eds., forthcoming 2016), http://ssrn.com/abstract=2213372 [https://perma.cc/3DJF-NEDS] (listing Plessy, Buck, and Korematsu as three of history's six most universally condemned Supreme Court decisions); Symposium, Supreme Mistakes, 39 PePP. L. REv. 1, 1-11 (2011) (discussing symposium on the "most maligned decisions in Supreme Court history," with three of the five contributions focusing on Plessy, Buck, and Korematsu); see also infra note 71 (placing Buck alongside "low points in Supreme Court history" like Plessy and Korematsu).

11. Cases that constitute "anticanon" are so antithetical to our social order that they stand for "a set of propositions that all legitimate constitutional decisions must be prepared to refute." Jamal Greene, The Anticanon, 125 HARV. L. REV. 379, 383 (2011) (defining "anticanon" and identifying Plessy and Korematsu as two of four Supreme Court decisions that meet that definition).

12. See CHEMERINSKY, supra note 1 , at $1-5$. 
hubristic, to the point of being almost unfathomable, for the Supreme Court in any of these cases to have ruled the other way.

Plessy, Buck, and Korematsu are worthy as case studies not because they show how the Supreme Court has failed us, but rather because they show how historical context can constrain the Justices' proclivity to protect. The Justices do not interpret the Constitution in a vacuum, let alone in a time capsule with the sensibilities of future years. They decide cases in a particular historical moment, and as such, are subject to the panoply of attitudes, assumptions-even prejudices-that define that moment in time. ${ }^{13}$ When the paradigm in which the Justices operate is racist, the Justices are likely to be racist. And when it is awash with support for civil liberties, there is a good chance the Justices will be too. What was true fifty years ago still holds true today: "The more widely held the values in society, the more likely the Supreme Court will hold them." 14

In prior work, I have endeavored to make this point by examining cases in which the Supreme Court ostensibly played the role of the countermajoritarian hero, protector of minorities from oppressive majority rule. On such highly controversial issues as capital punishment, abortion, and school prayer, I have historically situated the Court's protection to show that it was a response to, and reflection of, larger sociopolitical change. ${ }^{15}$ Here I turn my attention from the Court-as-hero to the Court-as-failure with the aim of showing that the flip side is also true-just as extralegal context can inspire the Supreme Court to protect, it can also limit its inclination to do so. Culture can both empower and constrain, ${ }^{16}$ and that is a problem for The Case Against the Supreme Court. Chemerinsky wants the Supreme Court to protect vulnerable minorities, but history shows

13. See Benjamin N. Cardozo, The Nature of the Judicial Process 168 (1921) (“The great tides and currents which engulf the rest of men do not turn aside in their course and pass the judges by.”). For Justice Holmes' articulation of the point, see infra note 146.

14. George D. Braden, The Search for Objectivity in Constitutional Law, 57 YALE L.J. 571, 594 (1948).

15. See Corinna Barrett Lain, Furman Fundamentals, 82 WASH. L. REV. 1, 19-45 (2007) (discussing larger sociopolitical context of Furman v. Georgia, 408 U.S. 238 (1972), invalidating the death penalty as then administered); Corinna Barrett Lain, God, Civic Virtue, and the American Way: Reconstructing Engel, 67 STAN. L. REV. 479, 489-506 (2015) (discussing the larger sociopolitical context of Engel v. Vitale, 370 U.S. 421 (1962), invalidating school prayer); Corinna Barrett Lain, Upside-Down Judicial Review, 101 GEO. L.J. 113, 133-44 (2012) (discussing the larger sociopolitical context of Roe v. Wade, 410 U.S. 113 (1973), recognizing a right to privacy in the context of abortion).

16. See Edward L. Rubin, The Supreme Court in Context: Conceptual, Pragmatic and Institutional, 69 VAND. L. REV. 1115, 1117 (2016) ("Real-world decision-makers necessarily function in political, economic, and social settings, and those settings both empower and constrain them.”). 
that when minorities are most vulnerable-when society is itself repressive-the Justices are least likely to see the need to protect.

Plessy, Buck, and Korematsu illustrate the point in three slightly different ways. Plessy shows how culture can limit the realm of plausible constitutional outcomes that a majority of the Justices might find agreeable. Buck shows how strong the gravitational pull of public opinion can be. And Korematsu shows how gusts of public passion can overtake the sensibilities of even those Justices most receptive to civil liberties claims. Three illustrations, one overarching point: the Supreme Court's proclivity to protect is in part a function of the historical context in which it is operating, and that limits what the Court can realistically do.

Three clarifications merit mention. First, this is not to say that cases like Plessy, Buck, and Korematsu should not be criticized. Condemning cases from the past for the value judgments they represent can help bring clarity to our value judgments going forward, whether or not the Justices could have decided those cases differently at the time. ${ }^{17}$ Indeed, the specter of our past may foment heightened sensitivity to minority rights in the future. ${ }^{18}$ But condemning obsolete values is different from condemning the Supreme Court as a failure because of them. The Court cannot escape the historical context in which it operates; it cannot transcend the mores of the society in which the Justices live. In short, the point is not that Plessy, Buck, and Korematsu aren't lamentable-they are. ${ }^{19}$ The point is that these lamentable cases were decided in lamentable times.

Second, this is not to say that the Justices' decisionmaking is historically predetermined. Sometimes historical context plays a determinative role in the Justices' decisionmaking, a point I aim to make with the case studies of Plessy, Buck, and Korematsu below. But what is true of those cases may not be true of others. Culture limits

17. As Jamal Greene put the point, "We are what we are not." Greene, supra note 11, at 381.

18. For example, Korematsu played this role in the wake of 9/11. See Roger Daniels, The Japanese American Cases, 1942-2004: A Social History, 68 L. \& ConTEMP. PRoBS. 159,170 (2005):

A striking difference is that although almost no public figures spoke out against the massive violations of the rights of citizens in 1942, the aftermath of 9/11 produced much public criticism of significantly lesser governmental violation of rights. And the analogy with the Japanese American experience was raised so often that it seems obvious that an increased awareness of its gross injustice was a factor in the heightened sensitivity within and without the government.

19. They are lamentable in the way that Aaron-Andrew Bruhl has recognized-as "old decisions emblematic of shameful social practices that, looking back, we wish someone had stopped." Aaron-Andrew P. Bruhl, Judicial Activism and the Problem of Induction, 16 GREEN BAG 2D 453, 454 (2013). 
the Supreme Court's proclivity to protect and therefore limits what it can realistically do, but within the realm of what is realistically possible, a number of other factors influencing the Justices' decisionmaking are also in play. ${ }^{20}$

Finally, this is not to say that an ahistoric view of the Supreme Court is all bad. Mostly it is-particularly for constitutional theory, which has been widely criticized for its inability to justify judicial review based on a realistic conception of how the Supreme Court operates. ${ }^{21}$ But an ahistoric, overinflated view of the Court's protective capacity has a curious upside as well. However historically inaccurate, the Supreme Court's image as a countermajoritarian hero ready and able to transcend its cultural constraints has set in motion forces that can, over time, ease those constraints and inspire the Court's protection. More remarkable yet is the Supreme Court's role in creating this image in the first place. With the Court as creator of the very expectations by which it is judged a failure, the fact of Chemerinsky's disappointment in the Supreme Court is itself a testament to a larger, and largely untold, story of Supreme Court success.

In this symposium contribution inspired by, and in response to, The Case Against the Supreme Court, I use Plessy, Buck, and Korematsu as case studies to show how historical context can constrain the Supreme Court's inclination to protect, limiting what the Court can realistically do. Part I places Plessy in its larger historical context, Part II turns to Buck, and Part III considers Korematsu. In Part IV, I discuss what we can learn from these historically reconstructed cases. I start with the recognition that historical context matters, nuancing the point by considering culture alongside other influences on Supreme Court decisionmaking. I then turn to three ways that culture can constrain the Justices' proclivity to protect, using Plessy, Buck, and Korematsu as illustrations. I close with a discussion of where, given the Court's inability to transcend its cultural constraints, the image of the Supreme Court as a countermajoritarian protector came from, and locate its origin in the Supreme Court itself. In numerous ways, I argue, the very notion of Supreme Court "failures" is itself evidence of a larger story of Supreme Court success.

20. For a more detailed discussion of the point, see infra notes 243-249 and accompanying text.

21. For a more detailed discussion of the point, see infra notes 240-241 and accompanying text. 


\section{PLESSY V. FERGUSON}

Chemerinsky describes the Supreme Court's 1896 decision in Plessy v. Ferguson ${ }^{22}$ as one of "the most tragically misguided Supreme Court decisions in American history." 23 In Plessy, the Supreme Court upheld "equal but separate" accommodations for African American railway passengers, legitimizing racial classifications for the next sixty years. ${ }^{24}$ Today, Plessy is considered so wrongly decided that its chief utility has become its status as a point of law for others to criticize. ${ }^{25}$

Chemerinsky acknowledges that the Justices in Plessy lived in a segregated society in which racism was deeply embedded, limiting what the Supreme Court could do. ${ }^{26}$ But he argues that the Justices "did not need to uphold 'separate but equal' in Plessy. It is quite justifiable to have expected the Court to do better." 27 After all, he writes, "There is no reason that a majority of the Justices could not have accepted Justice Harlan's reasoning in Plessy." 28 Justice Harlan dissented, the argument goes, so the other Justices could have, and should have, seen the injustice too.

Why Justice Harlan voted as he did in Plessy is a question I set aside for the moment and return to below. ${ }^{29}$ First, however, I provide a more robust historical perspective of the case than a mere acknowledgement that society was segregated allows. Without that perspective, it is easy to condemn the Justices in Plessy. With it, Chemerinsky's claim that the Supreme Court could have, and should have, done better becomes exceedingly difficult to make.

22. 163 U.S. 537 (1896).

23. Chemerinsky, supra note 1, at 37; see also Michael J. Klarman, Rethinking the Civil Rights and Civil Liberties Revolutions, 82 VA. L. REV. 1, 25 (1996) ("It is fair to say that Plessy is generally vilified today as one of the two most egregious decisions in Supreme Court history (along with Dred Scott).").

24. Plessy, 163 U.S. at 550-51; Sherry, supra note 10, at 15 ("Plessy allowed Jim Crow laws to deepen, racism to become more entrenched, and the status of African Americans to deteriorate for almost 60 years.").

25. That is what makes it anticanon. See Greene, supra note 11, at 386 ("[Anticanon are cases] so wrongly decided that their errors . . . we would not willingly let die. It remains important for us to teach, to cite, and to discuss these decisions, ostensibly as examples of how not to adjudicate constitutional cases.").

26. See Chemerinsky, supra note 1, at 30 ("To be fair, there is plenty of blame to go around, and racism was deeply embedded in the country, limiting what any court could do."); id. at 293 ("The justices who approved 'separate but equal' in Plessy lived in a society that was racially segregated.").

27. Id. at 337 .

28. Id. at 38 .

29. See infra notes 59-65 and accompanying text (discussing possible reasons for Justice Harlan's dissent). 
The story starts not with the fall of Reconstruction in the mid1870 s (as frequently told), but rather in the late 1880s and early $1890 \mathrm{~s}$, when race relations in the South took a sharp turn for the worse. ${ }^{30}$ Black lynchings soared, tripling what they had been just a decade earlier and hitting historic highs in 1892. ${ }^{31}$ States adopted legal measures to formalize the disenfranchisement of blacks already occurring through threats of violence. ${ }^{32}$ And state-mandated segregation replaced extensive de facto segregation on railways and other means of mass transport. ${ }^{33}$ Indeed, the Louisiana law at issue in Plessy was one of nine state statutes passed between 1887 and 1892 that imposed de jure segregation on railways. ${ }^{34}$ In light of the spike in violence towards blacks at the time, de jure segregation was widely justified as "enlightened public policy"-a distinctly progressive response to interracial conflict-although it was racist through and through. ${ }^{35}$

A number of forces drove these developments, exacerbating racism throughout the country: the migration of blacks to the North, increasing racial anxiety there; 36 the growing political power of poor white farmers in the South, intensifying demands for white

30. See Charles A. Lofgren, The Plessy Case: A Legal-Historical Interpretation 8 (1987) (noting that draconian racist measures associated with end of reconstruction in 1870s actually occurred from the late 1880s to 1900); Michael J. Klarman, The Plessy Era, 1998 SuP. Ст. REv. 303, 309 (discussing "long downward spiral" in race relations by late 1880s).

31. See Michael J. Klarman, Race and the Court in the Progressive Era, 51 VAND. L. REv. 881, 888-89 (1998) (noting "a dramatic deterioration of southern race relations during the 1890s" and that "the annual number of black lynchings rose dramatically, peaking early in the decade"). In 1882, 49 African Americans were lynched. In 1892, that number was 161. See Lynchings: By Year and Race, UMKC, http://law2.umkc.edu/faculty/projects/ftrials/shipp/ lynchingyear.html (last visited May 11, 2016) [https://perma.cc/CTP5-FD3W].

32. See Klarman, supra note 31, at 889 ("[S]outhern states adopted formal measures such as poll taxes, literacy tests, and residency requirements to supplement the de facto disfranchisement of blacks already accomplished through violence and fraud by the late 1880s.").

33. See LOFGREN, supra note 30, at 7-27 (discussing the move from de facto to de jure segregation of public transportation in the late 1880 s and $1890 \mathrm{~s}$ ).

34. See id. at 22 (listing states).

35. Alfred Holt Stone, Studies in the American Race Problem 64 (1908) ("As a matter of fact, such legislation is the embodiment of enlightened public policy, and is the surest guarantee of a minimum amount of friction between the races."); see also Klarman, supra note 30 , at 387 ("The Court acquiesced in railroad segregation at a time when deteriorating southern race relations convinced many southern blacks of the futility of protesting such practices, and racial violence and lynching made segregation increasingly appear to be reasonably progressive policy.”).

36. See Michael J. Klarman, From Jim Crow to Civil Rights: The Supreme Court and THE STRUGGLE FOR RACIAL EQUALITY 12 (2004) (discussing larger phenomenon and noting that " $[t]$ he growing numbers of blacks in the North led to discrimination in public accommodations, occasional efforts to segregate public schools, increased lynchings, and deteriorating racial attitudes."). 
supremacy as a means of elevating their precarious social status; ${ }^{37}$ the immigration of millions of Southern and Eastern Europeans in the 1880 s and '90s, triggering racial nativism in the Northeast and newfound sympathy for the South's position on race; 38 a growing desire for sectional reconciliation, providing yet another reason to defer to the South on race; ${ }^{39}$ the Republican Party's solidification of power in the early to mid-1890s, reducing its reliance on the Southern black vote and its commitment to the protection of black rights; ${ }^{40}$ a new generation of Southern blacks unschooled in the strictures of racial etiquette under slavery; ${ }^{41}$ and for railways in particular, the growing importance of interstate travel and the attendant need for social control. ${ }^{42}$

Taken together, these forces created a landscape where white supremacy was so entrenched that it was, as one historian put the point, "beyond critical reach in the late nineteenth century." 43 The public discourse at the time was filled with declarations of the inferiority of African Americans-their intellect, their moral code,

37. See id. at 11 (discussing larger phenomenon and noting that "[t]he growing political power of poor white farmers, whose precarious economic and social status inclined them to treasure white supremacy, did not bode well for blacks").

38. See id. at 12 (discussing larger phenomenon and noting that "Northerners concerned about the dilution of 'Anglo-Saxon racial stock' by Italian Catholics and Russian Jews were attracted to southern racial policies.").

39. See id. at 13 (discussing larger phenomenon and noting that "[t]he pace of sectional reconciliation accelerated in the $1890 \mathrm{~s}$, as northerners acquiesced in southern racial 'home rule." ").

40. See id. at 14-15 (discussing larger phenomenon and noting that Republican Party wins in 1894 and 1896 allowed it to "maintain national control without southern electoral support, thus removing an important incentive to defend black suffrage in the South").

41. See LOFGREN, supra note 30 , at 25 :

But the most direct trigger for the initial wave of Jim Crow legislation was increasing black unwillingness to defer to whites. A new generation, raised outside the confines of slavery and the web of antebellum restrictions on free blacks, was coming of age. Negro newspapers perceived growing black assertiveness in the face of indignities inflicted by whites; and among the white population, stories of 'uppity' Negroes increased during the 1880s.

See also KLARMAN, supra note 36, at 18 (discussing larger phenomenon and noting that "[a]nother view is that these laws may have been directed toward a younger generation of blacks, unschooled in traditional racial etiquette.").

42. See KLARMAN, supra note 36 , at 18 ("As southern railway transportation expanded after the war, black and white strangers came into closer proximity, leading to novel legislative efforts at social control."); $i d$. at 23 ("The same monopoly status that enabled railroads to set unreasonable rates also permitted them to ignore the segregationist preferences of white travelers. Thus, even libertarians often found railroad segregation statutes justifiable.").

43. LOFGREN, supra note 30, at 115 (quoting JOHN HALLER, OUTCASTS FROM EVOLUTION: SCIENTIFIC ATTITUDES OF RACIAL INFERIORITY, 1859-1900, at 210 (1971)); see also KLARMAN, supra note 36, at 22 (quoting a Northern newspaper in 1896 observing that the notion of social equality between blacks and whites was "more unthinkable today than ever"). 
their capacity to achieve-and it was prevalent on both sides of the sectional divide. ${ }^{44}$ Equally striking was the dearth of contestation of those claims. ${ }^{45}$

Indeed, even the most prominent African American leaders at the time espoused separatist views. This was the era of Booker T. Washington, who expressed his support for de jure segregation in his famous Atlanta Exposition Address of 1895, stating, "In all things that are purely social we can be as separate as the fingers, yet one as the hand in all things essential to mutual progress." 46 Washington thought that agitation over social equality was "extremist folly" and that integration could not be achieved by "artificial forcing." 47 Even W.E.B. Du Bois, who would later oppose Washington on this point, said at the time:

We must ever keep before us the fact that the South has some excuse for its present attitude. We must remember that a good many of our people are not fit for the responsibilities of republican government. When you have the right sort of black voters, you will need no election laws. The battle of my people must be a moral one, not a legal or physical one. ${ }^{48}$

With even black leaders supporting the racist status quo, it is hard to imagine a bench of white Justices espousing a more progressive view. As previously noted, the dominant understanding at the time was that "separate but equal" was the progressive view. ${ }^{49}$

44. See LOFGREN, supra note 30, at 94-99, 106-10 (discussing ideas of black intellectual and moral infirmity that dominated public forums in the North and South); id. at 99 ("Pervasive as these views were in the South, perhaps the more significant consideration is that the attitudes crossed sectional lines.").

45. See id. at 110-11 (discussing lack of critical response to such open espousals of black inferiority and noting, "To say no one objected is not literally true. Among other dissenters, Frederick Douglass levied a withering attack on the idea of Negro inferiority in all its manifestations. . . B But Douglass died in 1895, and while he lived his influence was waning, his call for integration and racial assimilation becoming more suspect.").

46. 3 Booker T. WAShington, The Standard Printed Version of the Atlanta Exposition Address, in The Booker T. WAShington PAPERS, Vol. 3: 1889-95, 585 (Louis R. Harlan ed., 1974); see also LOFGREN, supra note 30, at 111 ("Booker T. Washington's later critic, W.E.B. Du Bois, identified Washington's Atlanta Exposition Address, on September 18, 1895, as the event that more than any other made him 'the one recognized spokesman of his ten million fellows and one of the most notable figures in a nation of seventy millions.' ").

47. WASHINGTON, supra note 46, at 586 ("The wisest among my race understand that the agitation of questions of social equality is the extremist folly, and that progress in the enjoyment of all the privileges that will come to us must be the result of severe and constant struggle rather than an artificial forcing.").

48. LOFGREN, supra note 30, at 114 (quoting W.E.B. DuBois in 1891).

49. See supra note 35 and accompanying text (noting that de jure segregation was viewed as "enlightened public policy" at the time); see also Klarman, supra note 30, at 338 ("According to the dominant contemporary understanding, segregation served the state interest in removing occasions for interracial friction and violence."). 
The prospect of the Supreme Court deciding Plessy the other way was slim-to-none for another reason as well-the law was stacked against it. The Fourteenth Amendment was clearly not intended to forbid racial classifications; language to accomplish that objective had been proposed by Reconstructionists, and rejected. ${ }^{50}$ Moreover, the same Congress that passed the Fourteenth Amendment had passed legislation to segregate D.C. schools. ${ }^{51}$ In addition, three decades of lower court decisions had sustained segregation on common carriers as a reasonable response to interracial friction and violence, and numerous lower courts had sustained segregated education against Fourteenth Amendment challenges. ${ }^{52}$ In short, the Supreme Court in Plessy was accurate in observing that de jure segregation had been "generally, if not universally, recognized as within the competency of the state legislatures in the exercise of their police power." 53 Indeed, the Court itself-with Justice Harlan in tow-had just sustained a state statute that imposed greater penalties for interracial fornication, so it had already rejected the conception of a colorblind Constitution that formed the basis of Harlan's dissent. ${ }^{54}$

Taken together, the law and the larger context made Plessy an easy case for the Justices, ${ }^{55}$ and the Supreme Court's opinion relied on both, stating:

In determining the question of reasonableness, [the state] is at liberty to act with reference to the established usages, customs and traditions of the people, and with a view to the promotion of their comfort and the preservation of the public peace and good order. Gauged by this standard, we cannot say that a law which authorizes or even requires the separation of the races is unreasonable, or more obnoxious to the Fourteenth Amendment than the acts of congress requiring separate schools for colored

50. See KLARMAN, supra note 36, at 18. Indeed, some Republicans opposed ratification of the Fourteenth Amendment as a result, while others supported it but lamented their inability to include a ban on racial classifications. See id.

51. See CHEMERINSKY, supra note 1 , at 36 (recognizing point); see also KLARMAN, supra note 36, at 19 ("Many northern whites, including some Republicans, still resisted black political rights, such as voting or jury service, and social rights, such as interracial marriage or school integration.”).

52. See KLARMAN, supra note 36, at 20 ("For three decades, the decisions of lower courts had generally sustained segregation. Two lines of precedent were especially relevant: cases that sustained railroad practices of segregation and those that upheld school segregation laws."); $i d$. at 20-21 (discussing case law).

53. Plessy v. Ferguson, 163 U.S. 537, 544 (1896).

54. See Pace v. Alabama, 106 U.S. 583 (1883); see also Plessy, 163 U.S. at 559 (Harlan, J., dissenting) ("Our Constitution is color-blind, and neither knows nor tolerates classes among citizens ... ."); Klarman, supra note 30, at 330 (discussing Pace in relation to Plessy).

55. See LOFGREN, supra note 30, at 197 (quoting Justice Brown as recalling that the Justices had "little difficulty" deciding Plessy). 
children in the District of Columbia, the constitutionality of which does not seem to have been questioned ....56

The legal landscape supported it, established custom supported it, black leaders supported it, and progressive policy arguments supported it. Little wonder Plessy received scant attention in the popular press. ${ }^{57}$ It was so utterly congruent with the tenor of the times that it was hardly deemed worthy of notice. ${ }^{58}$

That leaves the question of Justice Harlan's dissent. If the injustice of Plessy was so hard to see, why was he able to see it? One answer is that society is not monolithic. Even at a time when support for segregation was pervasive, there would have been outliers with seemingly radical views. ${ }^{59}$ Indeed, the Supreme Court's division in Plessy may well have mirrored that of society more generally-elite and popular opinion were aligned on the issue of segregation, but this is not to say that there were no dissenters. ${ }^{60}$

Other, more personal explanations also come to mind. Justice Harlan had a black half-brother, "an intelligent, articulate, enterprising figure who achieved considerable success within the black community." 61 Robert Harlan had been born a slave, but had purchased his freedom from his father. ${ }^{62}$ It is possible that Robert influenced Justice Harlan's views, although even Robert was known to express "crude racial humor" about uneducated blacks, as was common among the "better' elements" of the African American community at the time. ${ }^{63}$ Perhaps more significant was the fact that Justice Harlan had been a vigorous supporter of reconstruction and

56. Plessy, 163 U.S. at 550-51.

57. See LOFGREN, supra note 30, at 196-97 (noting that "the most common press response was simply routine notice of the case, or no mention at all" and that the New York Times reported the decision on page three, in its regular Tuesday column on railway news, rather than on page one, where it reported several other Supreme Court decisions that day).

58. See id. at 197 ("The indifference greeting Plessy had a still more fundamental source. ... It embodied conventional wisdom.”); Benno C. Schmidt, Jr., Principle and Prejudice: The Supreme Court and Race in the Progressive Era, Part 1: The Heyday of Jim Crow, 82 Colum. L. REV. 444, 469 (1982) ("So closely did Plessy mirror the spirit of the age, however, that the country hardly noticed."); Klarman, supra note 30, at 334 ("The strongest evidence that Plessy coincided with northern [as well as southern] white opinion is the generally indifferent reaction to the decision.").

59. See Klarman, supra note 30, at 332-33 (recognizing point).

60. See id. at 306 ("[T] here was no evident disparity between elite and popular attitudes on issues like racial segregation ...."); id. at 320 ("Moreover, the relatively little we know about the racial views of the Plessy Court Justices suggests no reason to doubt that their predilections roughly mirrored that of the general population."); supra note 45 (quoting historian as noting, "To say no one objected is not literally true").

61. Tinsley E. Yarbrough, Judicial Enigma: The First Justice Harlan 141 (1995).

62. Id. at 141 .

63. See id. at 141-42 (discussing Justice Harlan's relationship with Robert Harlan). 
the ideals it represented before joining the bench. ${ }^{64}$ The Justice's close friendship with Frederick Douglass, who two decades earlier had been one of the most visible black leaders of the reconstruction era and was an ardent supporter of egalitarianism, also likely impacted his views. ${ }^{65}$

Even so, Justice Harlan likewise reflected the normative assumptions of his time. His dissent in Plessy was tinged with racial animus for Asians, ${ }^{66}$ and just three years after Plessy, he wrote the unanimous opinion in a Supreme Court decision that upheld separate and unequal education, sustaining Georgia's defunding of its only black high school. ${ }^{67}$ Perhaps Justice Harlan's reconstructionist views were limited to de jure segregation; perhaps he was just inconsistent. Whatever the reason, at least this much is true: Justice Harlan may have been prescient on segregation, but he was hardly colorblind.

In sum, to portray Plessy as a moral failure-a case where the Supreme Court could have, and should have, done better-is to fail to appreciate the historical context in which it was decided. The values that animated Plessy are widely repudiated today, but they were a part of the cultural milieu in which the Justices were operating at that time. Indeed, in light of the social, political, and legal landscape of 1896, it is hard to imagine the Justices ruling any other way than they did. ${ }^{68}$ Plessy's attorney knew this. He had appealed to the Supreme Court but was in no hurry for its ruling, noting, "The Court has always been the foe of liberty until forced to move on by public opinion." 69 Ironically, his case-Plessy-is Exhibit A for that being true.

64. See id. (discussing Justice Harlan's reconstructionist views and noting that when he was nominated to the bench, one black official told him that he was "well thought of by the influential colored man for what he believes to have been your interest in behalf of his oppressed race").

65. Id. at $142-43$ (discussing friendship with Frederick Douglass); see also supra note 45 (noting that Frederick Douglass was an exception to the silence that met open espousals of black inferiority, but he died in 1895 after waning popularity and influence).

66. See Plessy v. Ferguson, 163 U.S. 537, 561 (1896) (Harlan, J., dissenting) ("There is a race so different from our own that we do not permit those belonging to it to become citizens of the United States. Persons belonging to it are, with few exceptions, absolutely excluded from our country. I allude to the Chinese race."); id. (explaining as a point of hypocrisy that a "Chinaman" can ride in the same transportation as a white person, when a black person cannot).

67. See Cumming v. Cty. Bd. of Educ., 175 U.S. 528, 542-45 (1899).

68. See Klarman, supra note 23, at 26 ("To portray Plessy as simply a product of racist judging is to fundamentally misunderstand it. Background social, political, economic, and ideological forces created a climate within which judicial invalidation of a railway segregation law would have been dramatically countermajoritarian, and indeed virtually unthinkable.").

69. LOFGREN, supra note 30, at 149 (quoting Plessy's attorney Albion Tourgee). Interestingly, even the choice of Homer Plessy for the test case, a man who was seven-eighths Caucasian with "the mixture of colored blood . . . not discernable in him," suggests some 


\section{BUCK V. BELL}

Decided in 1927, Buck v. Bell upheld the forced sterilization of women of childbearing age deemed "idiotic, imbecile, feeble-minded or epileptic." 70 As others have noted, Buck is widely considered to be one of the worst decisions in Supreme Court history, earning its place next to Plessy and Korematsu in the Supreme Court "hall of shame." 71 Buck is bad in part because it gave the green light to forced sterilization (and thousands upon thousands ensued). ${ }^{72}$ And Buck is bad in part because its jarring rhetoric came from one of the most revered jurists of all time-Oliver Wendell Holmes. ${ }^{73}$ It was Justice Holmes who wrote the infamous line, "Three generations of imbeciles are enough,"74 leaving us all a little less innocent of the Court's imperfections than before. Of Buck $v$. Bell, Chemerinsky understandably asks, "How could the Supreme Court have failed so miserably?"75

One answer is that Buck v. Bell had little chance of coming out the other way; the parties had colluded on its outcome from the start. To understand the point requires some understanding of the legal landscape at the time. Between 1907 and 1922, a dozen states passed

appreciation that it would be an uphill battle from the start, as did the fallback position in the case that Plessy had been misclassified. See Plessy, 163 U.S. at 552 ("Under the allegations of his petition, it may undoubtedly become a question of importance whether, under the laws of Louisiana, the petitioner belongs to the white or colored race.”).

70. See Buck v. Bell, 274 U.S. 200 (1927).

71. See Paul A. Lombardo, Three Generations, No Imbeciles: Eugenics, the Supreme COURT, AND BUCK V. BELL xiii (2008) ("The Buck case represents one of the low points in Supreme Court history—on a par with Plessy v. Ferguson, which announced the now-discredited legal doctrine of 'separate but equal,' and the Korematsu case, which permitted the internment of Japanese citizens during World War II."); Victoria Nourse, Buck v. Bell: A Constitutional Tragedy from a Lost World, 39 PEPP. L. REV. 101, 101 (2011) ("A mere five paragraphs long, Buck $v$. Bell could represent the highest ratio of injustice per word ever signed on to by eight Supreme Court Justices, progressive and conservative alike.").

72. See CHEMERINSKY, supra note 1, at 4 ("Thousands more were surgically sterilized as a result of this decision. In the United States, by 1935, more than twenty thousand forced sterilizations had occurred ....").

73. See id. at 3 ("None other than the eminent Justice Oliver Wendell Holmes Jr., regarded as one of the greatest jurists in American history, wrote the opinion for the Court against her."); CoHEN, supra note 10, at 1 (noting that Justice Holmes is "widely considered to be one of the greatest legal minds-if not the greatest-in American history"); Robert J. Cynkar, Buck v. Bell: "Felt Necessities" v. Fundamental Values?, 81 Colum. L. REV. 1418, 1460 (1981) (referring to Holmes as "one of the patron saints of modern civil liberties").

74. Buck, 274 U.S. at 207.

75. CHEMERINSKY, supra note 1 , at 4 . 
involuntary sterilization laws of the type at issue in Buck. ${ }^{76}$ As Chemerinsky notes, most of the courts to consider their constitutionality had struck them down, although it also merits mention that every one of those cases was decided on procedural grounds. ${ }^{77}$ No court had held that states lacked the power to sterilize their feebleminded; the hitch was how they were going about it. ${ }^{78} \mathrm{In}$ 1922, a treatise analyzed these lower court cases and proposed a model code designed to withstand legal scrutiny. ${ }^{79}$ Virginia passed its sterilization law in 1924 based on this model code, and its backers were in search of a test case to validate it. ${ }^{80}$ That case was Buck $v$. Bell.

The facts could not have been better suited for their purpose. Virginia's sterilization statute applied only to those who had been institutionalized for hereditary feeblemindedness (or other allegedly hereditary disorders) and who were capable of bearing children. ${ }^{81}$ Carrie Buck fit the bill perfectly. She had been sent to the Virginia Colony for the Epileptic and Feebleminded just after the birth of her illegitimate daughter, Vivian. ${ }^{82}$ When she arrived at the Colony, her mother Emma was already there, having been committed to the Colony four years earlier. ${ }^{83}$ Carrie was almost eighteen, but had an

76. See Paul A. Lombardo, Disability, Eugenics, and the Culture Wars, 2 ST. LoUIS U. J. HEALTH L. \& POL'Y 57, 61 n.33 (2008) (listing twelve states that passed involuntary sterilization statutes).

77. See Chemerinsky, supra note 1, at 4 ("In fact, most lower courts to consider the issue prior to Buck v. Bell had declared involuntary sterilization unconstitutional."); see also Cynkar, supra note 73, at 1434 ("In the litigation which arose from these laws, the sterilization plans of seven states were held unconstitutional.").

78. See Cynkar, supra note 73, at 1446 ("It was true that seven sterilization laws had been struck down by lower courts, but all seven states had been guilty of procedural irregularities. Significantly, the eugenic idea itself had consistently been accepted by every judicial forum in which it had been argued.").

79. See generally HARRY H. LAUGHLIn, EUGENICAL STERILIZATION IN THE UNITED STATES: A REPORT OF THE PSYCHOPATHIC LABORATORY OF THE Municipal COURT OF CHICAGO (1922).

80. See LOMBARDO, supra note 71, at 97 ("The language ... used [in Virginia's law] and the arguments for the hereditary nature of mental and physical defects were taken, in many places verbatim, from Harry Laughlin's Model Law, printed in Eugenical Sterilization in the United States."); id. at 102 (noting that the Colony's advocate in the Virginia General Assembly "advised that all sterilizations be postponed until the Virginia law had been validated by the Court of Appeals of Virginia and 'possibly the Supreme Court of the United States' ").

81. See Cynkar, supra note 73, at 1436-37 (discussing Virginia's sterilization statute).

82. See LOMBARDO, supra note 71, at 103-05 (discussing Carrie Buck's pregnancy and subsequent commitment to the Colony).

83. See id. at 105-06 (discussing Emma Buck's arrival at the Colony and describing her as suffering from pneumonia, rheumatism, and syphilis, with scars from intravenous injections suggesting illicit drug use). 
estimated mental age of nine. ${ }^{84}$ Her mother Emma had an estimated mental age of eight, ${ }^{85}$ and her daughter Vivian, who was still an infant, had been described as "not quite right." ${ }^{6}$ Hence, the "three generations of imbeciles"-the word "imbecile" tracking the language of the statute, which in turn tracked the technical term used by professionals at that time. ${ }^{87}$

But the facts were not what made the case a surefire loser for Carrie Buck; it was her lawyer. As it turns out, Carrie's lawyer was a close confidant of the lawyer for the Colony, as well as an ardent sterilization supporter. ${ }^{88}$ In fact, he had been a founding member of the Colony's board of directors, with a building there bearing his name. ${ }^{89}$ At trial, Carrie's attorney did not contest the state's right to deprive the feebleminded of the ability to procreate. ${ }^{90}$ Nor did he contest the notion that feeblemindedness was hereditary, or that Carrie (or her mother or her daughter) was feebleminded. ${ }^{91} \mathrm{He}$ called no witnesses, offered no evidence, and presented no defense. ${ }^{92}$ In short, Buck v. Bell was the quintessential friendly suit. Carrie's attorney cross-examined the witnesses (sort of) and made procedural

84. Her IQ was listed as fifty-six. Id. at 105; see also id. at 107 (noting mental age of nine when tested at age eighteen); Cynkar, supra note 73, at 1437 (noting that Carrie Buck was committed "a few weeks before her eighteenth birthday and shortly after the birth of her illegitimate child"); but see infra note 91 (noting room to doubt whether findings of feeblemindedness were true).

85. Cynkar, supra note 73, at 1418. Emma's IQ was listed as fifty. LOMBARDO, supra note 71 , at 106 .

86. See LOMBARDO, supra note 71, at $\mathrm{x}$ ("Experts had examined the infant, saying she was 'below average' and 'not quite right' ....").

87. Buck v. Bell, 143 Va. 310, 312 n.* (1925) (quoting 1924 Va. Acts 569); Nourse, supra note 71 , at 104 (“' ‘I]mbecile' along with 'moron' and 'idiot' were technical terms used by sociologists, psychologists, zoologists, and even geneticists of the day.”).

88. LOMBARDO, supra note 71 , at 107.

89. See id. at xi (noting that Carrie Buck's lawyer "was a founding member of the Virginia Colony's board of directors and a major supporter of the sterilization campaign"); CoHEN, supra note 10, at 98 (noting that the Colony had a building named in honor of the man who represented Carrie Buck to recognize his role in its history).

90. Rather, he conceded it. Brief for Plaintiff in Error at 13, Buck v. Bell, 274 U.S. 200 (1927) (No. 292) ("We concede that the State has the right to segregate the feebleminded and thereby deprive them of the 'power to procreate.'"); see also Cynkar, supra note 73, at 1448 (noting that Carrie Buck's lawyer "never challenged the eugenical idea which shaped the public policy, nor questioned the power of the state to execute that policy by some means").

91. LOMBARDO, supra note 71, at 152-53. This is arguably the real tragedy in the case, as there is considerable room to doubt whether Carrie was in fact feebleminded, or her daughter, or even her mother. See Cynkar, supra note 73, at 1458 (noting that Carrie's daughter Vivian had completed second grade when she died from childhood measles and was considered "very bright"); Lombardo, supra note 76, at 62 ("[T] he real story of the Bucks was much more complex: Carrie herself had been raped, her daughter Vivian was perfectly normal, and the case itself was a fraud.").

92. See LOMBARDO, supra note 71, at 118-20, 152-54 (detailing representation). 
claims, ${ }^{93}$ but he failed to put the state's case to any serious test. Lamenting the result in Buck v. Bell, one Catholic priest wrote to another at the time that he wished the girl's lawyer had mounted a better defense, but since that had not happened, "I do not see how the court could have rendered any other decision in view of the facts before it." 94 The facts were uncontested, the statute carefully drawn, and the procedural protections scrupulously followed. ${ }^{95}$ One reason Buck $v$. Bell came out the way it did is because the parties never intended it to come out the other way.

But even if that had not been the case, it is hard to fathom the Supreme Court ruling other than it did in light of the tenor of the times. To understand why requires some understanding of the eugenics movement that dominated the first three decades of the twentieth century ${ }^{96}$ - a movement that emerged around the turn of the century from the confluence of several bodies of thought. The first was social Darwinism, "survival of the fittest" applied to the human experience in society. ${ }^{97}$ "If they are sufficiently complete to live, they

93. See id. at 118, 126-27 (reproducing portions of cross examination of Colony's expert witness); Cynkar, supra note 73, at 1446-48 (discussing arguments in brief challenging sterilization statute). Carrie Buck challenged the sterilization law on due process and equal protection grounds. Buck, 274 U.S. at 205. The Supreme Court rejected both in unequivocal terms. See id. at 207:

There can be no doubt that, so far as procedure is concerned, the rights of the patient are most carefully considered, and, as every step in this case was taken in scrupulous compliance with the statute and after months of observation, there is no doubt that, in that respect, the plaintiff in error has had due process of law.

See also id. at 208:

But, it is said, however it might be if this reasoning were applied generally, it fails when it is confined to the small number who are in the institutions named and is not applied to the multitudes outside. It is the usual last resort of constitutional arguments to point out shortcomings of this sort. But the answer is that the law does all that is needed when it does all that it can ....

94. Christine Rosen, Preaching Eugenics: Religious Leaders and the American EUGENICS MOVEMENT 151 (2004).

95. See supra note 93 (quoting opinion in Buck v. Bell).

96. See Steven Selden, Inheriting Shame: The Story of Eugenics and Racism in AMERICA 1 (1999) ("In the early decades of the $20^{\text {th }}$ century, the assumptions that race and heredity were central to human development and social progress were basic components of American social thought."); Cynkar, supra note 73, at 1420 (noting the "hereditarian attitudes that had shaped social thought in America during the first three decades of the twentieth century").

97. See John Higham, Strangers in the LAND: PAtTerns of AMERICAN NATivism 18601925 , at 135 (1955) ("What stood out in the first instance, as the great social lesson of the theory of natural selection, was not the ravages of the struggle for survival but rather the idea of 'the survival of the fittest.'"); RICHARD HOFSTADTER, SOCIAL DARWINISM IN AMERICAN THOUght 6 (1955) ("The most popular catchwords of Darwinism, 'struggle for existence' and 'survival of the fittest,' when applied to the life of man in society, suggested that nature would provide that the best competitors in a competitive situation would win, and that this process would lead to 
live and it is well that they should live. If they are not sufficiently complete to live, they die and it is best they should die," wrote Herbert Spencer, the leading social Darwinist, in 1851.98 Next was the work of Francis Galton, who believed that the traits that determined society's "fittest" were inherited, producing numerous studies to that effect and coining the term "eugenics"-the "science of good breeding"-in 1883. ${ }^{99}$ Then in 1900, the rediscovery of Gregor Mendel's work on pea plants gave eugenics the scientific explanation it had lacked.100 Mendel found that when he cross-fertilized pea plants, certain traits were transmitted in predictable ways; some traits were dominant, some were recessive, and one could control outcomes by recognizing the two. ${ }^{101}$ With the last piece of the puzzle in place, the eugenics movement was born.

For many, it came just in the nick of time. The development of early IQ tests suggested that genetic feeblemindedness and degeneracy were on the rise, distressing professionals and creating massive anxiety among the public. ${ }^{102}$ The concern was not just about the cost of caring for the feebleminded and the strain it put on the

continuing improvement."); Cynkar, supra note 73, at 1420 ("Social Darwinists saw the existing social order as the result of healthy competition in which the 'fittest' survived.").

98. HeRbert SPENCER, Social StATICS 380 (1851). Ironically, what came to be known as social Darwinism in fact predated Darwinism by almost a decade. Compare SPENCER, supra, with CHARLES DARwin, ON THE ORIGIN OF SPECIES (1859). Thanks to Eric Berger for sharing this insight.

99. See Francis Galton, HeREditary Genius: AN INQUiRy into its LAWs AND CONSEQUENCES (1869); FRANCIS GALTON, InQUiRIES INTO HUMAN FACUlTy AND ITS DEVELOPMENT 44 (1883); see also HiGHAM, supra note 97, at 150 (discussing Galton's work); LOMBARDO, supra note 71, at xi (referring to eugenics as the "science of good breeding"); SELDEN, supra note 96, at 2 (also discussing Galton's work).

100. See HOFSTADTER, supra note 97, at 163 (noting that "Mendel's studies in heredity placed in the hands of geneticists the organizing principle which their inquiries had lacked and gave them fresh confidence in the possibilities of their research for prediction and control"); LOMBARDO, supra note 71, at 30 (discussing Mendel's work); Cynkar, supra note 73, at 1421 (same).

101. See SELDEN, supra note 96, at 2-3; Cynkar, supra note 73 , at 1421.

102. See CoHEN, supra note 10 , at 25 ("The nation was in the midst of a panic over feeblemindedness."); Cynkar, supra note 73, at 1424:

The past few years have witnessed a striking awakening of professional and popular consciousness of the widespread prevalence of feeblemindedness and its influence as a source of wretchedness to the patient himself and to his family, and as a causative factor in the production of crime, prostitution, pauperism, illegitimacy, intemperance, and other complex social diseases....

(quoting S.P. DAvies, Social Control of the FeEbleminded 56 (1923)); see also SELDEn, supra note 96, at 23-27 (discussing and reproducing pictures of various displays at exhibitions and state fairs such as "Some People Are Born to Be a Burden on the Rest," which illustrated with flashing lights how "the rising tide of bad heredity" was threatening the nation's economic wellbeing); Cynkar, supra note 73, at 1423-25 (discussing early Binet-Simon IQ tests and alarming results). 
public coffers and private charities; 103 it was also the fear that the "weak in mind" were "weak in will" and thus more likely to propagate, exacerbating the problem. ${ }^{104}$ "Those least fit to carry on the race are increasing most rapidly," wrote progressive feminist and birth control advocate Margaret Sanger, echoing prevailing wisdom at the time. ${ }^{105}$ With the degenerate population rising and the prospect of a multiplier effect making it worse, the question of what to do about it became the most pressing question of its time. ${ }^{106}$

Eugenics offered an answer. For eugenicists, feeblemindedness was a congenital defect, a simple Mendelian recessive. ${ }^{107}$ Although few eugenicists advocated denying help to those who needed it so social Darwinism could run its course, most favored controlling the number of unfit going forward as the preferred alternative to building more institutions to house them. ${ }^{108}$ Charity just allowed degenerates to keep

103. See NANCy ORdover, American Eugenics: Race, QueER ANATOMy, AND the Science OF NATIONALISM 147 (2003) ("Every year millions of dollars are collected in taxes and spent on the maintenance of the defective, the feeble-minded, the insane and the criminals." (quoting Unprofitable Children: Are These Bodies Fit Temples for Immortal Souls?, 5 BIRTH CONTROL REV. 129, 144 (1924)); id. ("Billions of dollars are expended by our state and federal governments and by private charities and philanthropies for the care, maintenance, and perpetuation of these classes." (quoting Margaret Sanger, Address of Welcome at the Sixth International NeoMalthusian Conference (March 25, 1925))); id. at 148 (quoting Margaret Sanger, Address of Welcome at the Sixth International Neo-Malthusian Conference (March 25, 1925)):

If the millions upon millions of dollars which are now being expended in the care and maintenance of those who in all kindness should never have been brought into this world were converted to a system of bonuses to unfit parents, paying them to refrain from further parenthood, and continuing to pay them while they controlled their procreative faculties, this would not only be a profitable investment, but the salvation of American civilization.

104. LOMBARDO, supra note 71, at 6; see also id. at 16 (noting that "the image of the "moral degenerate,' a woman defective in mind as well as morals, remained a powerful rallying point for various kinds of reformers who would ultimately endorse the twin policies of segregation and sterilization"); id. at 118 ("[A] feebleminded girl is much more likely to go wrong.") (quoting Transcript of Record at 65-69, Buck v. Bell, 130 S.E. 516 (Va. 1925)).

105. ORDOVER, supra note 103, at 140 (quoting Margaret Sanger, The Eugenic Value of Birth Control Propaganda, BIRTH ConTROL REV., no. 10, Oct. 1921, at 5).

106. See id. at 140 ("[T]he most urgent problem today is how to limit and discourage the overfertility of the mentally and physically defective." (quoting Margaret Sanger, The Eugenic Value of Birth Control Propaganda, BIRTH CONTRol REV., no. 10, Oct. 1921, at 5)); CoHEN, supra note 10 , at 25 (quoting editorial opining that "of all the matters facing state governments, "none is more pressing than the care of the feeble-minded" "); see also infra text accompanying note 136 (quoting Michigan Supreme Court as noting the "growing belief that, due to the alarming increase in the number of degenerates, criminals, feeble-minded, and insane, our race is facing the greatest peril of all time").

107. See Cynkar, supra note 73 , at 1422 .

108. See, e.g., Charles B. Davenport, Eugenics: The Science of Human Improvement BY BetTer BREEDING 31-32 (1910) (read before the American Academy of Medicine at Yale University, Nov. 12, 1909):

Shall we as an intelligent people, proud of our control of nature in other respects, do nothing but vote more taxes or be satisfied with the great gifts and bequests that 
breeding, they argued. ${ }^{109}$ Degeneracy was inherited, so the solution was simple-stop propagating the strain that produced it. ${ }^{110}$ In one, maybe two generations, the problem would take care of itself. 111 Genetic problems allowed for genetic solutions, the argument went.112 And so it was that the eugenic premise was also its promise-that science could be harnessed to prevent suffering, protect the physical and fiscal health of future generations, and make society a better place. ${ }^{113}$ It was seductively sensible and optimistic, which was part of what made it so popular. ${ }^{114}$

philanthropists have made for the support of the delinquent, defective and dependent classes? Shall we not rather take the steps that scientific study dictates as necessary to dry up the springs that feed the torrent of defective and degenerate protoplasm?

See also LOMBARDO, supra note 71, at 50 (noting that eugenicists saw euthanasia as effective but "too dear a moral price").

109. See LOMBARDO, supra note 71, at 19 (noting eugenic "conventional wisdom: mental defect was hereditary; charity only encouraged people to multiply irresponsibly; excessive tax money was spent on social welfare-and the amount was growing").

110. See Cynkar, supra note 73, at 1428 (noting the "fundamental premise [of eugenics] that 'much social inadequacy is of a deep-seated biological nature, and can be remedied only by cutting off the human strains that produce it" "quoting HARRY H. LAUGHLIN, EUGENICS RECORD

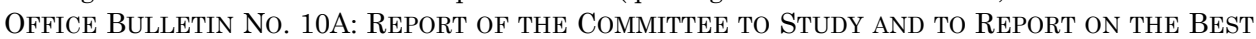
Practical Means of Cutting OfF the Defective Germ-Plasm in the American Population 54-55 (1914))); Michelle Oberman, Thirteen Ways of Looking at Buck v. Bell: Thoughts Occasioned by Paul Lombardo's Three Generations, No Imbeciles, 59 J. LEGAL EDUC. 357, 374 (2010) ("It is a vicious cycle; ignorance breeds poverty and poverty breeds ignorance. There is only one cure for both, and that is to stop breeding these things." (quoting MARGARET SANGER, WHAT EvERY BOY AND GIRL SHOULD KNOW 140 (1915))).

111. See LOMBARDO, supra note 71, at 50 (noting the eugenic goal to "largely but not entirely eliminate from the race the source of supply of the great anti-social human varieties within two generations"); Cynkar, supra note 73, at 1425 (quoting the president of the University of Wisconsin in 1914 as stating, "We know enough about eugenics so that if the knowledge were applied, the defective classes would disappear within a generation.”; and MARK HALLER, EUGENICS: HEREDITARIAN ATTITUDES IN AMERICAN THOUGHT 76 (1963)).

112. See SELDEN, supra note 96, at 36 (quoting Charles Davenport) ("Man is an animal, and permanent racial progress in eugenics must be based on the laws of biology."); Kevin E. Grady, $A$ Review of Three Generations, No Imbeciles: Eugenics, the Supreme Court, and Buck v. Bell, 26 GA. ST. U. L. REV. 1295, 1299 (2010) (“[T]he eugenic premise that mental disorders and social problems were linked to genetic inheritance and that the major ills of society (crime and poverty) could be cured through a selective control of heredity.").

113. See Paul A. Lombardo, Taking Eugenics Seriously: Three Generations of ??? are Enough?, 30 FLA. ST. U. L. REV. 191, 211 (2008) ("The attraction to eugenics for many was that it promised, if not a medical Utopia, free of diseases, at least a future in which some debilitating conditions could be relegated to the dustbin of history."); Oberman, supra note 110, at 359 (noting that "eugenics-based activism was imbued with their conviction that they had a deep responsibility to protect and promote the future of civilization").

114. See Lombardo, supra note 113, at 208 (noting that the "clearly philanthropic motive" of the eugenics movement is what made it "extraordinarily popular"); $i d$. at 211 (noting the "seductive message of the eugenics movement ... that science could be used to alleviate suffering and improve the human condition"). 
And popular it was. The eugenics movement appealed to conservatives with its social Darwinism and fiscal responsibility, and to progressives with its pragmatic approach to social reform. ${ }^{115}$ Little wonder that leaders across a wide range of fields were vocal supporters. ${ }^{116}$ The first six presidents of the twentieth centuryTheodore Roosevelt, William Taft, Woodrow Wilson, Warren Harding, Calvin Coolidge, and Herbert Hoover-all supported eugenics. ${ }^{117}$ So did more than a dozen Nobel Peace Prize winners from the sciences, including the nation's top two geneticists. ${ }^{118}$ Leaders in higher education supported eugenics, as did "the father of American medical education," William Welch, who served as the first dean of the school of medicine at Johns Hopkins and as president of the American Medical Association. ${ }^{119}$ Winston Churchill, Alexander Graham Bell, Thomas Edison, Hellen Keller-Hellen Keller-Margaret Sanger, Jack London, and Anthony Comstock all endorsed eugenics. ${ }^{120}$ Wealthy philanthropists and their foundations supported it too. ${ }^{121}$

At the grassroots level, evidence of the popularity of eugenics was pervasive. There were "better babies" and "fitter families" contests at state fairs, eugenic films, books, textbooks, traveling exhibitions, sermon contests, and even eugenic marriage certificates

115. See CoHEN, supra note 10, at 57 ("At the same time, eugenics exerted a strong appeal to conservatives. Many were drawn to its insistence that there was a natural elite and that . . helping the genetically disadvantaged would only increase the number of criminals and welfare cases."); SELDEN, supra note 96, at 24 ("[Eugenics] were the proposals of a progressive organization, made during the Progressive Era, and they drew progressive supporters."); Edward J. Larson, Putting Buck v. Bell in Scientific and Historical Context, 39 PEPP. L. REv. 119, 120 (2011) ("No one party or ideology was to blame. At the time, eugenics laws of the type enacted in Virginia were supported by conservatives and progressives; Republicans and Democrats; scientists and lay people, Christians and Jews.”).

116. See Mark A. Largent, BreEding Contempt: The History of Coerced Sterilization IN THE UNITED STATES 2-3 (2008) (discussing "those responsible for the tens of thousands of coerced sterilizations" and noting that "American biologists were merely one segment of a movement that included thousands of scientists, politicians, social activists, philanthropists, educators, and assorted do-gooders, racists, and utopians.").

117. See Lombardo, supra note 76 , at 74 .

118. See Larson, supra note 115, at 123; Lombardo, supra note 113, at 209.

119. See Larson, supra note 115, at 123; Lombardo, supra note 113, at 212.

120. See Larson, supra note 115, at 123; Lombardo, supra note 113, at 210-11; Grady, supra note 112, at 1297. Helen Keller's support may be explained by the fact that she became deaf and blind from a childhood illness, rather than hereditary condition. See Larson, supra note 115, at 123.

121. See Grady, supra note 112, at 1297 ("Major philanthropists, such as the Carnegie Foundation, E.M. Harriman, and John D. Rockefeller helped fund eugenic efforts . . ..”); Larson, supra note 115, at 123 ("Wealthy philanthropists and foundations vied to support eugenics research and lawmaking."). 
issued by the Surgeon General. ${ }^{122}$ By 1915, eugenics was so popular that it had become a fad, ${ }^{123}$ although its followers fervently denied it. "Eugenics is a science. It is a fact, not a fad," wrote the Assistant Surgeon General at the time. ${ }^{124}$

In the first two decades of the twentieth century, eugenic ideology (and the ideologies it served) found expression in numerous areas of the law. Anti-miscegenation statutes were hardly new, but added to their rank were "eugenic marriage laws" that required premarital testing for certain conditions and prohibited marriage of the unfit. ${ }^{125}$ The Immigration Act of 1924 and the draconian quotas it set on immigrants from Southern and Eastern Europe likewise represented a eugenic (and racist and nativist) attempt to protect the integrity of Anglo-American stock. ${ }^{126}$ Even more explicit were institutionalization and sterilization statutes, which directly implemented the eugenics ideal. By 1927, when the Supreme Court decided Buck $v$. Bell, twenty-seven of the forty-eight states had sterilization statutes, and many more had provisions to

122. See COHEN, supra note 10, at 3-4, 59-62 (same); see also LOMBARDO, supra note 71, at 45,55 (discussing eugenic certificate issued by surgeon general, as well as eugenic books and plays); SELDEN, supra note 96, at 23-36 (discussing various phenomena illustrating popularity of eugenics).

123. See HofsTADTER, supra note 97, at 161 ("Eugenics then grew with such great rapidity that by 1915 it had reached the dimensions of a fad."); see also HIGHAM, supra note 97, at 150-51 (noting that from 1910 to 1914 "the general magazines carried more articles on eugenics than on the three questions of slums, tenements, and living standards, combined").

124. Lombardo, supra note 113, at 210 (quoting assistant Surgeon General Dr. W.C. Rucker).

125. See CoHEN, supra note 10, at 63 (discussing eugenic marriage laws and noting that "Marriage prohibitions were a major advance for the eugenics movement: they were the first laws to endorse the goal of reducing reproduction of the "unfit.'"); LOMBARDO, supra note 71, at 46 (noting that "laws requiring testing for syphilis or other conditions that affected fertility were routinely labeled 'eugenic marriage laws," and that some clergymen "would perform no marriages ... until the parties to the union obtained a 'clean bill of health' ").

126. See CoHEN, supra note 10, at 132-35 (discussing role of eugenicists in passing the Immigration Act of 1924); ORDOVER, supra note 103, at 1 (quoting Biological Aspects of Immigration, Hearings Before the H. Comm. on Immigration and Naturalization, 66th Cong. 3 (1920) (statement of Harry H. Laughlin, Secretary, Eugenics Research Ass'n):

The character of the nation is determined primarily by its racial qualities; that is, by the hereditary physical, mental, and moral or temperamental traits of its people .... It is now high time that the eugenical element, that is, the factor of natural hereditary qualities which will determine our future characteristics and safety, receive due consideration.;

see also HighAM, supra note 97, at 151 ("From the eugenicists' point of view, the immigration question was at heart a biological one, and to them admitting 'degenerate breeding stock' seemed one of the worst sins the nation could commit against itself."); Cynkar, supra note 73, at 1427 (noting that eugenics "did much to put growing American nativism and racism on a 'scientific' basis"). 
institutionalize feebleminded women of childbearing age until they were no longer fertile. ${ }^{127}$

In the early years, institutionalization was viewed as the more genteel option. ${ }^{128}$ Even Catholics, who thought reproductive matters were for God alone to decide, tended to support institutionalization. ${ }^{129}$ But as time passed, the tide turned. "It is vastly more humane to relieve these individuals of a function which they cannot properly use and allow them to return to their homes or society than to keep them confined in an institution for the greater part of their young lives," argued supporters of sterilization. ${ }^{130}$ Sterilization was physically invasive, but it gave the feebleminded their freedom, accomplished the eugenic objective, and was less taxing than institutionalization on the public fisc. ${ }^{131}$ In short, it was progressive.

None of this is to deny that within the scientific community, there were growing concerns about the genetic claims that eugenicists made. But such scientific debates played out mostly in the pages of obscure journals and were slow to change the predominant view. ${ }^{132}$

127. See Nourse, supra note 71, at 104 (discussing statutes); see also LOMBARDO, supra note 71, at 18 (discussing Virginia's 1912 institutionalization law for feebleminded "women of childbearing age, from twelve to forty-five years of age"); Larson, supra note 115, at 124 (discussing state sterilization statutes and noting that "[m]any more states enacted measures to compel the sexual segregation of mentally ill or retarded persons").

128. See Cynkar, supra note 73, at 1429 (noting that "[a] nationwide plan of mandatory, long-term custodial care" was widely deemed to be "the most human method" of preventing propagation and that compulsory sterilization was viewed as "a quite drastic step" that "for many, directly assaulted the sense of human dignity").

129. See Rosen, supra note 94, at 148 (describing the Catholic view of institutionalization "as a form of 'kindly detention' that served the best interests of society without violating the natural rights of the feebleminded" and thus could "enjoy Catholic support"); id. at 151 ("[A]ll Catholic authorities admit that such persons as the one whose case came before the Court may be segregated and prevented from becoming parents in state institutions and colonies." (quoting Letter from John A. Ryan to J.G. Hearty (May 9, 1927))).

130. Cynkar, supra note 73, at 1430 (quoting John H. Bell enunciating "the classic rationale for eugenic sterilization”).

131. See CoHEN, supra note 10, at 5 ("Segregation was expensive: states could not build enough institutions to house all the people the eugenicists wanted to stop from having children. Sterilization, however, was completely effective, and it could be carried out on a mass scale.”); LOMBARDO, supra note 71, at 96-98 (discussing economic and other grounds for sterilization as opposed to institutionalization, and noting that "the implication was clear that life outside of an institution, even after sterilization, was better than life within one").

132. See LOMBARDO, supra note 71, at 56 ("[T] so-called eugenic marriage laws, disagreement among scientists remained muffled, generally hidden in the pages of obscure journals. The public heard other voices ...."); Cynkar, supra note 73 , at $1455-56$ ("It took over a decade for newer studies to overcome the attitudes generated by the early eugenic research. Most of the serious criticism of eugenic ideas was just beginning in the 1920s."); see also LARGENT, supra note 116, at 97-99 (discussing "voices of opposition before Buck" and noting that "By and large, early opponents to coerced sterilization were lone voices in their professions, and they were inconsistent in attacking some aspects of the compulsory 
Not until the 1930s did the eugenics movement start to wane-in part because of scientific advances, ${ }^{133}$ and in part because its champions died or retired and no one stepped up to the helm. ${ }^{134}$ As we now know, the Justices in Buck $v$. Bell were not presented with evidence of early qualms about the scientific basis for eugenics. ${ }^{135}$ Yet even if they had been, there is reason to doubt it would have made a difference; the one court that heard such evidence in 1925 thought the scientific basis still sound and upheld sterilization as a valid exercise of the state's police power "based on the growing belief that, due to the alarming increase in the number of degenerates, criminals, feebleminded, and insane, our race is facing the greatest peril of all time." 136 This was the context in which the Supreme Court decided Buck v. Bell.

The decision was relatively easy for the Justices; progressives, conservatives, and even the Supreme Court's libertarians joined in the

sterilization laws while supporting others. Before the late $1920 \mathrm{~s}$, it was rare to find an author who unequivocally rejected the idea of coerced sterilizations . .."); id. at 116 ("Beginning in the early 1930s, some of the American professions that supported eugenics and compulsory sterilization, including physicians, social scientist, and biologists, slowly withdrew their support.").

133. See Larson, supra note 115, at 127 (discussing the 1936 report of the American Neurological Association "which some historians credit with turning the tide of American scientific opinion against compulsory eugenics"; and ABRAHAM MYERSON ET AL., EUGENICAL SteRILIZATION: A REORIENTATION OF THE PROBlem 177-83 (1936)); see also Cynkar, supra note 73 , at 1456 (explaining that in the 1930s, "studies in other social sciences began to shift thought away from purely hereditarian explanations of human behavior").

134. See id. ("In the 1930s, the passionately committed leaders of eugenics died or retired and no one stepped forward to replace them."). Interestingly, some authors have contended that the Nazi's use of American eugenics also led to its demise-and that is true, but that development did not occur until well after the 1930s. See LARGENT, supra note 116, at 139 ("While it is evident that coerced sterilization continued well through the 1950s and that there is little evidence to support claims that the Holocaust turned Americans against compulsory sterilization after the war, the comparisons between the American eugenics movement and the policies of the Nazis finally wielded powerful rhetorical force in the last decades of the twentieth century. Throughout the 1970s and 1980s, biologists and historians alike frequently linked coerced sterilization to the World War II atrocities."); LOMBARDO, supra note 71, at 232 (noting the "common misconception" that Nazi practices led to the popular rejection of eugenics in the 1930s); see also LARGENT, supra note 116, at 7 (noting that even as late as 1937, a Fortune magazine poll showed that sixty-six percent of respondents supported sterilization for mental defectives).

135. See supra notes 90-92 and accompanying text (discussing poor representation of Carrie Buck).

136. Smith v. Wayne, 231 Mich. 409, 425 (1925); see also id. at 424:

That feeble-mindedness is hereditary in certain cases, there can be no doubt. While a difference of opinion undoubtedly exists as to whether the condition of feeblemindedness in a particular person is such that it is reasonably certain his children will, or will not, be affected thereby, we are of the opinion that the weight of authority, as evidenced by scientific writings and reports, are convincing that it may be so determined. 
Buck opinion. ${ }^{137}$ At the time, the notion that states could regulate in the interest of health and welfare as an exercise of their inherent police powers was so entrenched and conventional as to border on the banal. ${ }^{138}$ Buck was decided in the Lochner era, so the Justices were deeply divided on the constitutionality of economic regulation, but as to the propriety of regulation in the interest of the public welfare-and eugenic sterilization unquestionably fell into that category-the doctrine was not in doubt. ${ }^{139}$

Even so, the enthusiasm with which the Supreme Court in Buck $v$. Bell affirmed Virginia's sterilization statute suggested that the Justices approved of more than mere police power. Writing for the Court, Justice Holmes described the statute's purpose as being "to prevent our being swamped with incompetence" and affirmed its legitimacy with the line, "It is better for all the world if, instead of waiting to execute degenerate offspring for crime or to let them starve for their imbecility, society can prevent those who are manifestly unfit from continuing their kind." ${ }^{140}$ Given that Justice Holmes had been a longtime supporter of eugenics, ${ }^{141}$ it would have been no surprise to see such language in one of his own opinions. But he was writing for virtually every member of the Supreme Court. Only Justice Butler dissented in Buck v. Bell, and he did not publish an opinion explaining why. ${ }^{142}$

Perhaps there was nothing to say. The Supreme Court had undisputed facts of three generations of feeblemindedness, an admittedly valid legislative purpose, scrupulous compliance with procedural protections, decades of doctrine, and a cultural context in which eugenic interventions were viewed as progressive public policy backed by science. Under those circumstances, it would have been wildly hubristic, to the point of being almost unimaginable, for the

137. See Nourse, supra note 71 , at 112-13 (discussing votes of Court's progressives, moderates, conservatives, and libertarians).

138. See id. at 113 ("Oxymoronic as it may sound, Buck v. Bell's implied police power analysis was banal as a doctrinal matter ....").

139. See id. at 112-14 (discussing how even the Lochner era's libertarians, the so-called "four horsemen" who staunchly defended labor and property rights, followed "the standard doctrine of the day—rights were subject to the police power").

140. Buck v. Bell, 274 U.S. 200, 207 (1927).

141. See Oliver Wendell Holmes, Ideals and Doubts, 10 ILL. L. REV. 1, 3 (1915):

I believe that the wholesale social regeneration which so many now seem to expect, if it can be helped by conscious, coordinated human effort, cannot be affected appreciably by tinkering with the institution of property, but only by taking in hand life and trying to build a race. That would be my starting point for an idea for the law.

142. Buck, 274 U.S. at 208 (noting only "Mr. Justice Butler dissents."). 
Justices in Buck to have ruled the other way. ${ }^{143}$ Even Justice Butler's dissent was understood at the time as a reflection of his idiosyncratic Catholic views. ${ }^{144}$

Today we view Buck $v$. Bell with derision and contempt. Labels like imbecile, feebleminded-even mentally retarded-are now considered gauche, or at least unenlightened. ${ }^{145}$ But it has been nearly ninety years since the decision; our sensibilities have dramatically changed. What Buck v. Bell teaches is not that the Supreme Court is a failure. It is that the Justices' view of the law is inextricably bound by what Oliver Wendell Holmes described in 1881: "The felt necessities of the time, the prevalent moral and political theories, intuitions of public policy, avowed or unconscious, even the prejudices which judges share with their fellow men.” 146

\section{KOREMATSU V. UNITED STATES}

The Supreme Court's 1944 decision in Korematsu v. United States, ${ }^{147}$ known for approving the internment of nearly 120,000 Japanese Americans during World War II (two-thirds of whom were United States citizens) has been called "the Court's greatest single failure ... in all its history." 148 The hardship that internment imposed

143. See Larson, supra note 115, at 124 (“[S]triking down Virginia's sterilization statute in 1927 would have constituted a blatant act of judicial activism bordering on hubris.").

144. See LOMBARDO, supra note 71, at 172 (noting that Justice Holmes told a colleague that Justice Butler was "afraid of the Church" and wagered, "I'll lay you a bet the Church beats the law" (quoting Drew Pearson \& Robert S. Allen, The Nine Old Men 117 (1936))); Larson, supra note 115, at 125 ("Butler knows this is good law', Holmes told a colleague before the ruling. 'I wonder whether he will have the courage to vote with us in spite of his religion.'” (quoting William E. Leuchtenburg, The Supreme Court Reborn: The Constitutional REvolution In the AGE of Roosevelt 15 (1995))); see also Cynkar, supra note 73, at 1452 ("At the time of Buck $v$. Bell, though the Church had made no official pronouncement, it generally opposed sterilization. This view became the official position of the Church in 1930 when Pope Pius XI condemned sterilization in an encyclical on Christian marriage."); LARGENT, supra note 116, at 10 ("The immediate impact of Buck v. Bell was the crystallization of Catholic opposition to sterilization.").

145. See Pub. L. No. 111-256, 124 Stat. 2643 (2010) (striking the words "mental retardation" and "mentally retarded" from the U.S. Code and replacing them with descriptors using the term "intellectual disabilities").

146. Oliver Wendell Holmes, The Common LaW 1 (1881).

147. 323 U.S. 214 (1944).

148. FRIEDMAN, supra note 6 , at 372 ; see also CHEMERINSKY, supra note 1 , at 58 ("[T]he Court's decision in Korematsu is regarded as one of its greatest embarrassments."); Sherry, supra note 10, at 15 ("Korematsu and Hirabayashi upheld the most invidious racially discriminatory regime since slavery, forced thousands to abandon their homes and livelihoods, and encouraged an anti-Asian bigotry that has since dissipated but not disappeared."); ERIC YAMAMOTO ET AL., RACE, Rights AND REPARATION: LAW AND THE JAPANESE AMERICAN INTERNMENT 38 (2001) 
was exceptionally severe physically, psychologically, and economically. ${ }^{149}$ And the dragnet it cast was based solely on Japanese ancestry-race. ${ }^{150}$ "The Court should have emphatically declared the government's acts unconstitutional," Chemerinsky writes. ${ }^{151}$ The vote in Korematsu was six-to-three, he argues, and if three Justices could see the injustice of a rule based on race, two more could have too. ${ }^{152}$

Why three Justices dissented in Korematsu and what to make of those dissents are questions I take up shortly; first, however, I flesh out the context in which Korematsu was decided and the contours of the decision itself. Chemerinsky recognizes that "[t]he justices who approved evacuation of Japanese Americans in Korematsu had lived through the early days of World War II, when the outcome was uncertain and patriotism meant supporting the government's war efforts." 153 And that much is true. But it misses what was actually driving the case-not patriotism or even the outcome of the war, but rather the threat of imminent invasion. Justice Black, author of Korematsu, had drafted a passage that did not appear in the final opinion but candidly captures the point:

When an enemy Army imminently threatens a particular area of our country with invasion, the immediate responsibility for defense must necessarily rest on those who direct our armed forces. ... It is enough for me that both Congress and the Commanderin-Chief of the Army made a decision that the regulation as made was necessary to provide for the common defense in an area in which no man could say whether or when armed invaders would appear. ${ }^{154}$

At issue in Korematsu was the judiciary's role as to actions taken while under the threat of imminent invasion. To understand why the Justices decided it the way they did, one must first understand the larger sociopolitical context in which they experienced the case.

(noting internment of nearly 120,000 persons of Japanese descent, over two-thirds of whom were American citizens).

149. For a moving account of what the internment experience was like for Japanese Americans, see generally Frank H. Wu, Frank J. Battisti Memorial Lecture, Difficult Decisions During Wartime: A Letter From a Non-Alien in an Internment Camp to a Friend Back Home, 54 CASE W. RES. L. REV. 1301 (2004); see also CHEMERINSKY, supra note 1, at 58 (noting that Japanese Americans lost $\$ 70$ million in farms, $\$ 35$ million in produce, and almost $\$ 500$ million in annual income).

150. See CHEMERINSKY, supra note 1, at 57 ("Korematsu is deeply objectionable because the government used ethnicity alone as the basis for predicting who was a threat to national security and who would remain free.").

151. Id. at 55 .

152. See id. at 58 (noting that "[t]his is not just hindsight" because several Justices dissented); $i d$. at 89 ("It is too easy to make excuses for the justices and say that it is unrealistic to have expected them to do better. On the contrary, the Court could have stood up to pressure, and the powerful dissents could have been the positions of the majority.").

153. CHEMERINSKY, supra note 1 , at 293.

154. ROGER K. NEWMAN, Hugo BLACK: A BIOGRAPHY 315 (1994) (quoting excerpt). 
The story starts with Japan's attack on Pearl Harbor on December 7, 1941, which knocked out the better part of the nation's Pacific fleet.155 Eleven ships sunk, 165 planes destroyed on the ground, and 2,500 people dead, with over a 1,000 more injured. ${ }^{156}$ America was in shock-there had been no declaration of war, no warning ${ }^{157}$-and Japan's invasion of the Philippines just hours after Pearl Harbor, with the graphic reports of brutality that followed, only added to the public's fear. ${ }^{158}$

More was yet to come. Just three days after Pearl Harbor, Japan sank two British battleships, leaving the entire South Pacific virtually unprotected. ${ }^{159}$ A string of Japanese military victories followed, inducing panic that an attack on the nation's vulnerable West Coast was next 160 _particularly in California, the self-described "number one war industry state."161 Reports of Japanese planes reconnoitering parts of California resulted in a massive blackout, and

155. See George Morgenstern, Pearl Harbor: The Story of the Secret War 51-67 (1947) (discussing the decision to move the Pacific Fleet from San Francisco to Pearl Harbor to deter Japanese aggression in the Far East).

156. See YAмамото ET AL., supra note 148, at 38 (discussing destruction from attack on Pearl Harbor); Wu, supra note 149, at 1309 (same).

157. The fact that the attack occurred while United States was in diplomatic negotiations with Japan, and without a declaration of war or advance notice, led President Roosevelt to declare December 7, 1941 as "a date which will live in infamy" in a speech delivered to a joint session of congress the following day. President Franklin Delano Roosevelt, Pearl Harbor Address to Congress, in 87 Cong. REC. 9504-05 (daily ed. Dec. 8, 1941); see also YAMAMOTO ET AL., supra note 148, at 97 (noting that Pearl Harbor attack shocked military leaders and the American public).

158. See Peter Irons, Justice AT WAR 8 (1983) (noting "graphic reports of brutality by Japanese troops as they overran the Philippines shocked the American public").

159. See 3 Winston Churchill, The Churchill War Papers: The Ever Widening War 1593-94 (2001):

In all the war I never received a more direct shock ... . As I turned and twisted in bed the full horror of the news sank upon me. There were no British or American capital ships in the Indian Ocean or the Pacific except the American survivors of Pearl Harbor, who were hastening back to California. Over all this vast expanse of waters Japan was supreme, and we everywhere were weak and naked.;

Del Dickson, The Supreme Court IN Conference 687 n.127 (2001) (“After Pearl Harbor, there was no effective American military presence in the Pacific, and military experts believed that a Japanese invasion of the West Coast was imminent.").

160. See Daniels, supra note 18, at 171 ("It was not just the disaster at Pearl Harbor, but the subsequent sequence of Japanese triumphs that triggered Executive Order 9066 seventy-four days later."); Roger Daniels, Incarcerating Japanese Americans, OAH MAG. HIST., Spring 2002, at 19, 20 ("But the terrible war news of the winter of 1941-1942, in which seemingly invincible Imperial Japanese forces overran the Philippines, much of Southeast Asia, and seemed to threaten Australia and perhaps the United States itself, produced a state of panic, especially on the West Coast.").

161. Sumi Cho, Redeeming Whiteness in the Shadow of Internment: Earl Warren, Brown, and a Theory of Racial Redemption, 40 B.C. L. REv. 73, 108 n.183 (1998) (quoting Earl Warren's 1942 gubernatorial campaign press release). 
although those reports turned out to be false, ${ }^{162}$ reports of Japanese submarines off the West Coast were true. Between December 17 and 23, Japanese subs attacked a number of U.S. merchant ships, sinking two tankers and damaging a freighter along the Pacific coast. ${ }^{163}$ The nation braced itself for attack along its western border, which was widely viewed to be imminent. ${ }^{164}$

Given the nation's long tradition of anti-Asian sentiment (particularly on the West Coast), the attack on Pearl Harbor alone may have led to a spike in animus against Japanese Americans, ${ }^{165}$ but exacerbating racial tensions was the strong suspicion that Japanese Americans had been involved in the attack. The FBI had broken into the Japanese consulate in Los Angeles earlier in 1941 and had recovered extensive information compromising Japan's West Coast espionage network. ${ }^{166}$ In the immediate wake of Pearl Harbor, federal agents had acted on that information, arresting over 2,000 Japanese Americans believed to have enemy loyalty. ${ }^{167}$ Rumors spread that the round-up was based on evidence of aiders and abettors in the Pearl Harbor strike, and those rumors gained traction when the Secretary of the Navy toured Pearl Harbor and stated that espionage had played a part. ${ }^{168}$ Newspapers sensationalized the comment with headlines that

162. See IRONS, supra note 158 , at 26.

163. See id. at 27.

164. See id. at 26 (noting that civilians and military "shared a severe case of Pearl Harbor panic" and that "[f]ears of an imminent Japanese attack on the West Coast swept through nearly all segments of the public in the weeks that followed Pearl Harbor").

165. See Cho, supra note 161, at 86-88 (discussing "California's long tradition of anti-Asian legislation, violence and intolerance”); Harvey Gee, Civil Liberties, National Security, and the Japanese American Internment, 45 SANTA CLARA L. REV. 771, 776-77 (2005):

"Even before the attacks on Pearl Harbor, Japanese immigrants and their Americanborn children endured great hardship in this country because they were perceived as economic threats. As such, they were subjected to official discrimination and political protest. Through legislation, boycotts, school segregation, and propaganda, the Japanese faced exclusion driven by fear and hostility. The flames of anti-Japanese animus were further fueled by the bombing of Pearl Harbor.

166. See YAMAMOTO ET AL., supra note 148, at 96-97 (discussing counterespionage break-in). For a fascinating account, see generally Pedro Loureiro, The Imperial Japanese Navy and Espionage: The Itaru Tachibana Case, 3 INT'L J. INTELLIGENCE \& COUNTERINTELLIGENCE 105-21 (1989); and Francis MacDonnell, Insidious Foes: The Axis Fifth Column and the AMERICAN Home Front 83-86 (1995).

167. See IRONS, supra note 158, at 19 (discussing roundup); YAMAMOTO ET AL., supra note 148, at 96-97 (discussing same in the relation to prior counterespionage break-in). It was the fact that the FBI had fresh intelligence on disloyal Japanese Americans from the break-in and had arrested over 2000 people that created the government's internal disagreement over the necessity of internment. See id. at 96-97 ("After these arrests, military intelligence and the FBI disagreed about how much espionage threat remained.").

168. See Irons, supra note 158, at 19 (" 'A great man hunt was underway last night in Southern California,' the Los Angeles Times reported on December 8, as federal agents 'sought 300 alien Japanese suspected of subversive activities.' "); YAMAMOTO ET AL., supra note 148, at 38 
read "Secretary of Navy Blames Fifth Columnists for Raid" and "Fifth Column Treachery Told," 169 setting off an avalanche of reports by nervous citizens of "signaling" coming from the California coastline. ${ }^{170}$ Cementing suspicions was the January 1942 report of the Roberts Commission-chaired by Justice Owen Roberts at the behest of President Roosevelt to investigate the attack on Pearl Harbor-which likewise concluded that espionage had been a contributing factor in the attack. ${ }^{171}$

That leaves two additional reasons Japanese Americans were viewed as suspect. One was California Attorney General Earl Warren's mapping project. Just after the release of the Roberts Commission Report, Warren met with county officials to collect information about Japanese American residential patterns. ${ }^{172}$ What he found was an unusual clustering of settlements near areas of strategic importance such as power plants, airports, freight yards, factories, and other industrial areas. ${ }^{173}$ Ignoring the fact that past discrimination against Japanese Americans often made marginal tracts near these areas their only available housing option, Warren saw in the settlement patterns an opportunity for large scale sabotage. ${ }^{174} \mathrm{He}$ shared his project with military leaders, syndicated columnists, and eventually Congress, and it is thought to have played

(discussing roundup in the immediate wake of Pearl Harbor and noting, "Soon, it became widely believed that Pearl Harbor succeeded because of Japanese American sabotage"); Cho, supra note 161, at 90 ("Two days after the December 7, 1941, Pearl Harbor attack, Secretary of the Navy Frank Knox toured the devastated site and put into circulation unfounded rumors that Japanese Hawaiian saboteurs were responsible for 'the most effective fifth-column work that's come out of this war." ").

169. Cho, supra note 161, at 90-91; see also Fifth Column, MERRIAM WebSTER DiCTIONARY, http://www.merriam-webster.com/dictionary/fifth\%20column (last visited Mar. 16, 2016) [https://perma.cc/YR64-AYN9] (defining fifth column as "a group of secret sympathizers or supporters of an enemy that engage in espionage or sabotage within defense lines or national borders").

170. See IRONS, supra note 158, at 27 (discussing point and noting military's receipt of "hundreds of reports nightly of signal lights visible from the coast").

171. See id. at 40 (discussing report's findings and noting that the report "inflamed the mainland press and spurred the incipient campaign for the mass evacuation of Japanese Americans from the West Coast"); Joseph A. Greenaway, Jr., The Weintraub Lecture: Judicial Decision Making and the External Environment, 51 RUTGERS L. REV. 181, 183-84 (1991) (discussing the Roberts Commission report and noting that its allegation that civilians were involved with the espionage effort "fueled the fire of race hate beyond repair"). Later investigation would reveal that espionage was involved in the Pearl Harbor attack, but the main culprit was a Japanese vice consul in Hawaii. For that account, see GoRDON PRANGE, AT DAWN We Slept: The Untold Story of PeARL Harbor (1981) (detailing espionage of Takeo Yoshikawa and its role in Pearl Harbor attack).

172. See Cho, supra note 161, at 92-93.

173. See id. at $93-94$.

174. See id. at $94-98$. 
a part in President Roosevelt's decisionmaking process. ${ }^{175}$ In the end, Warren's mapping project and influence would earn him the dubious distinction of being "the single most powerful voice" for the internment decision. ${ }^{176}$

The second reason that Japanese Americans were suspect in the wake of Pearl Harbor was their Japanese ancestry itself. Japanese Americans were known as a tight-knit, largely unassimilated group, and many believed that their past mistreatment gave them good reason to be disloyal. ${ }^{177}$ The Niihau incident at Pearl Harbor, in which Japanese Hawaiians had helped a downed Japanese zero pilot overcome his captors and secure weapons, ${ }^{178}$ likewise gave credence to the view that "race, culture, custom and religion" might outweigh American citizenship in determining loyalty-especially since many Japanese American citizens were considered Japanese citizens too. ${ }^{179}$ It was racist, blatantly so, and at times infused with clear anti-Asian

175. See id. at 99-105 (discussing the significance of Warren's mapping project). The project ultimately found its way to the Supreme Court. See Hirabayashi v. United States, 320 U.S. 81, 105 (1943) (Douglas, J., concurring) ("The presence of many thousands of aliens and citizens of Japanese ancestry in or near to the key points along that coast line aroused special concern in those charged with the defense of the country.").

176. Frank F. Chuman, The Bamboo People: The LaW and Japanese-Americans 151 (1981); see also Cho, supra note 161, at 89-90 (quoting Chuman and other scholars who claim Warren was "one of the individuals most responsible for bringing the relocation program into being" and that "probably more than any single person" Earl Warren influenced the internment decision).

177. See Hirabayashi, 320 U.S. at 96 :

There is support for the view that social, economic and political conditions which have prevailed since the close of the last century, when the Japanese began to come to this country in substantial numbers, have intensified their solidarity and have in large measure prevented their assimilation as an integral part of the white population.

The government made this argument in its brief, stating:

The reaction of the Japanese to their lack of assimilation and to their treatment is a question which of course does not admit of any precise answer. It is entirely possible that an unknown number of the Japanese may lack to some extent a feeling of loyalty toward the United States as a result of their treatment, and may feel a consequent tie to Japan .... .

YАMАMOTO ET AL., supra note 148, at 123.

178. See Allan Beekman, The Nimhau Incident: The True Story of the Japanese Fighter Pilot Who, After the Pearl Harbor Attack, Crash-Landed on the Hawaitan ISLAND OF NIIHAU AND TERRORIZED THE RESIDENTS (1982) (discussing the Niihau Incident, which was cited in General DeWitt's final report recommending internment).

179. Korematsu, 323 U.S. at 237 (Murphy, J., dissenting). Under Japan's dual citizenship doctrine, children born to Japanese nationals were citizens of Japan too. The military relied on this doctrine as part of its justification for internment, although as Justice Murphy noted in his Korematsu dissent, that doctrine had been modified and was generally no longer in play. See id. at 237-38 (Murphy, J., dissenting). 
animus. ${ }^{180}$ But these fears, too, were part of the larger sociopolitical context of the case.

Fear, vulnerability, suspicion of espionage, race-these factors combined in early 1942 to create a torrent of calls for the removal of Japanese Americans from the West Coast as a preventive measure. The popular press called for it. ${ }^{181}$ The governors of California, Oregon, and Washington called for it too, as did other West Coast politicians. ${ }^{182}$ Indeed, California Attorney General Earl Warren's part in the internment decision-his mapping project-was a prominent part of the gubernatorial campaign that would sweep him into office in the fall of 1942. ${ }^{183}$ General John DeWitt, head of the Western Defense Command responsible for defending the Pacific Coast, called for internment too-partly in response to Pearl Harbor panic, partly in response to political lobbying, and partly in response to the Roberts Commission report's finding that lax readiness played a role at Pearl Harbor, a lapse he felt intense pressure to prevent from happening again. ${ }^{184}$

In February 1942, less than ninety days after the Pearl Harbor attack, President Roosevelt signed Executive Order 9066, authorizing the military to designate specified areas as military zones "from which any or all persons may be excluded" and to impose restrictions in those areas as appropriate. ${ }^{185}$ Congress followed the next month with Public Law 503, which criminalized failure to follow military orders in those zones, passing the measure by a voice vote-unanimously in the

180. See Greenaway, supra note 171, at 184 (quoting General Dewitt as saying to a congressional committee, "A Jap's a Jap; it makes no difference whether he's an American citizen or not. There is no way to determine his loyalty").

181. See IRONS, supra note 158, at 7 (noting "demands for the removal of Japanese Americans from the West Coast" in the press and quoting the Los Angeles Times as editorializing, "the rigors of war demand proper detention of Japanese and their immediate removal from the most acute danger spots"); id. ("Flowing toward the White House through the tributaries of public opinion, these currents of concern about the Japanese Americans began as a trickle and ended as a torrent."); YАMAMOTO ET AL., supra note 148, at 99 (noting that prominent newspaper journalists and syndicated columnists supported internment); Daniels, supra note 18, at 162 (quoting New York Times article stating "There appeared last week ample proof to substantiate Pacific Coast fears.").

182. See Greenaway, supra note 171 , at 184; see also IRONS, supra note 158 , at 268-69 (noting pressure from "West Coast politicians" including "the West Coast congressional delegation").

183. See Cho, supra note 161, at 105-11 (discussing role of mapping project in Warren's 1942 gubernatorial campaign and quoting from campaign ads to illustrate point).

184. See IRONS, supra note 158, at 26-27, 268; YAMAMOTO ET AL., supra note 148, at 99.

185. Exec. Order No. 9066, 7 Fed. Reg. 1407 (Feb. 25, 1942) (authorizing the Secretary of War to prescribe military areas); see also IRONS, supra note 158, at 7 (discussing executive order). 
Senate. ${ }^{186}$ With that and a few derivative orders, internment began. ${ }^{187}$ General DeWitt declared the entire West Coast to be a theatre of operations under military control, imposing a curfew on Japanese Americans in March and excluding them from the area (by interning them in another) in May. ${ }^{188}$ The public supported the move. ${ }^{189}$

Indeed, one of the most striking aspects of the sociopolitical context of 1942 is the dearth of public criticism of internment, even among those one would expect to express a contrary view. ${ }^{190}$ The Japanese American Citizens League (JACL) supported internment, encouraging its members to comply and declining to assist those who did not. ${ }^{191}$ The Communist Party also supported internment and instructed its members to comply, despite its commitment to making democracy look bad by defending the rights of oppressed minorities, as it had famously done in the Scottsboro Boys case a decade earlier. ${ }^{192}$ Even the ACLU was deeply split on the issue, with the national board ultimately deciding that local ACLU branches were "not free to

186. See An Act of March 21, 1942 to Provide a Penalty for Violation of Restrictions or Orders with Respect to Persons Entering, Remaining in, Leaving, or Committing Any Act in Military Areas or Zones, Pub. L. No. 77-503, 56 Stat. 173 (1942); see also Klarman, supra note 23 , at 29 (noting that congressional authority was granted by a voice vote after perfunctory debate); Daniels, supra note 160, at 20 (noting that the measure passed unanimously in the Senate, although it was considered one of the "sloppiest" laws "read or seen anywhere").

187. See IRONS, supra note 158, at 321 (noting that Congress also appropriated funds for relocation after passing Public Law 503); Greenaway, supra note 171, at 185 (discussing second executive order, Executive Order 9102, establishing the War Relocation Authority).

188. See DiCKSON, supra note 159, at 687; IRONS, supra note 158, at 6; YAMAMOTO ET AL., supra note 148 , at $101,104$.

189. Barry Friedman writes:

Gallup did remarkably little polling on the question [of internment], which is itself telling of how little most people really seemed to care what was going on. But the answers Gallup did elicit are a little chilling. In 1942, Gallup asked whether those interned inland should be allowed to return at the end of the hostilities. By a 48-34 margin, the answer was no.

Friedman goes on to say that in follow-up questions about what should happen to the interned Japanese Americans, "the most popular responses advocated throwing them out of the country or sending them back to Japan, and 3.8 percent indicated they should just be killed." FRIEDMAN, supra note 6, at 373; see also Robert H. Jackson, Wartime Security and Liberty Under Law, 1 BUFF. L. REV. 103, 115 (1951) (describing internment as "certainly the popular view at the time").

190. See Daniels, supra note 18, at 162 ("It is notorious that virtually no protest was heard against the mass violation of the civil liberties of Japanese Americans during the war, either from the ethnic community before it was sent to camp or from the larger public then and later.... both the press and those organizations that had been the traditional defenders of the civil liberties of minorities were silent."). Even the defendant in the companion case to Hirabayashi, when asked what he would do if he were in charge, answered, "I feel that I would intern all Japanese aliens and Japanese citizens." IRONS, supra note 158, at 140 (quoting Yasui).

191. See IRONS, supra note 158, at 79-81 (discussing position of JACL); YAMAMOTO ET AL., supra note 148 , at 129 (same).

192. See Daniels, supra note 18, at 163 (noting that the communist party "supported mass incarceration and instructed its few Japanese American members to go willingly to the camps"). 
sponsor cases in which the position is taken that the government has no constitutional right to remove citizens from military areas." ${ }^{193}$ As important as civil liberties were, the exigencies of war took precedence. ${ }^{194}$

Against this backdrop, one would think that the Supreme Court would have readily approved the military's orders-and it did in two curfew cases decided in 1943, when the outcome of the war was still very much in doubt. ${ }^{195}$ In Hirabayashi $v$. United States and the companion case of Yasui v. United States, the Justices unanimously rejected a constitutional challenge to military curfew restrictions applicable only to Japanese Americans. ${ }^{196}$ While recognizing that "distinctions between citizens solely because of their ancestry are by their very nature odious," the Court cited "the danger of espionage and sabotage in a time of war and of threatened invasion" as justification for sustaining the race-based restriction. ${ }^{197}$ Even so, the Justices strained to decide as little as they could; the cases were brought as challenges to the military's internment order, but the Court affirmed on the ancillary curfew violations instead. ${ }^{198}$

193. IRONS, supra note 158, at 130 (quoting national ACLU); see also id. at ix, 128-30, 36061 (discussing the "fierce internal battle within the ACLU" pitting a local California branch against the ACLU's national board, which voted not to challenge constitutionality of internment); Klarman, supra note 23, at 29 ("Even the American Civil Liberties Union was bitterly divided over the constitutionality of the military exclusion order, ultimately concluding that the demands of national security during wartime could justify exclusion of citizens from a military zone."). Ultimately, the ACLU filed an amicus brief in Korematsu challenging internment after several of its members connected with two Department of Justice attorneys who were likewise conflicted over the internment decision. For the saga, see IRONS, supra note 158, at 130-32, 186-95 (discussing the ACLU's positioning in the Japanese American cases after having declined direct representation).

194. See IRONS, supra note 158, at 133-34 (asking:

What factors led the only independent organization dedicated to defending the rights of racial and political minorities to withhold support from those who challenged the uprooting of an entire racial group from its homes? .. . Why did the ACLU by a 2-to-1 margin refuse to sanction direct challenges to the President's power to authorize the military orders directed at Japanese Americans?

and answering with a discussion of how wartime concerns trumped civil liberties).

195. See Yамамото ET AL., supra note 148, at 163 ("When the early pair of cases (Hirabayashi and Yasui) were considered by the Supreme Court in 1943, fighting in the Pacific was fierce and U.S. success was by no means assured.").

196. Hirabayashi v. United States, 320 U.S. 81, 109-14 (1943); Yasui v. United States, 320 U.S. 115, 117 (1943).

197. Hirabayashi, 320 U.S. at 100.

198. See IRONS, supra note 158, at 231-50 (discussing conference and other discussions among the Justices in Hirabayashi to rule as narrowly as possible); Greenaway, supra note 171, at 185 (discussing Hirabayashi's intent to be a test case against internment and how he came to be charged with curfew violations as well, which ultimately formed the basis for the Court's decision). 
In fairness, the sociopolitical context had changed substantially by the time the Supreme Court decided Korematsu v. United States and its companion case, Ex Parte Endo, in December 1944. ${ }^{199}$ In the fifteen months after Hirabayashi, the war had shifted strongly in the allied forces' favor, with decisive battlefield victories in both the Pacific and in Europe. ${ }^{200}$ West Coast fears of a Japanese invasion had largely faded and the nation was more confident about World War II's outcome. ${ }^{201}$ Indeed, by the summer of 1944 , high level cabinet debates over when to end internment were already well underway. ${ }^{202}$

Yet the fear that gripped the nation in the wake of Pearl Harbor, and the urgency it created for protective measures in response, were still fresh in the Justices' minds. "The need for action was great, and time was short," the Supreme Court in Korematsu wrote. ${ }^{203}$ Invasion appeared to be imminent, the military had concluded that mass internment was necessary, and the President and Congress had agreed. For a majority of the Justices, that was enough. ${ }^{204}$ As the last line of the majority's opinion put the point, "We cannot-by availing ourselves of the calm perspective of hindsightnow say that, at that time, these actions were unjustified." ${ }^{205}$ The moment of crisis had passed, but the Justices remembered it vividly. More to the point, they refused to invalidate a racial classification in hindsight that a unanimous bench had held valid when the danger was still acute.

199. Korematsu v. United States, 323 U.S. 214 (1944); Ex Parte Endo, 323 U.S. 283 (1944).

200. See IRONS, supra note 158, at 319-20:

Both in the Pacific and Europe, the tides of war had shifted dramatically in the fifteen months since the Court had decided the Hirabayashi and Yasui cases. Fresh from bloody but decisive victories in the Mariana Islands, American troops were poised to return General Douglas MacArthur to the Philippines. Allied troops in Europe flowed through their beachhead in Normandy in pursuit of the retreating Germans, while Soviet soldiers battled their way toward Berlin.

201. See DiCKSON, supra note 159, at 693; YAMAMOTO ET AL., supra note 148, at 163.

202. See YAMAMOTO ET AL., supra note 148, at 174; see also IRONS, supra note 158, at 269 (noting that the President decided not to end internment in summer of 1944, despite advice from military advisors that it was no longer necessary, because he wanted a partisan advantage in the 1944 elections, but that these were "behind-the-scenes" discussions of which the litigants were unaware).

203. Korematsu, 323 U.S. at 223-24.

204. See id. at 218-19:

We cannot say that the war-making branches of the Government did not have ground for believing that, in a critical hour, such [disloyal] persons could not readily be isolated and separately dealt with, and constituted a menace to the national defense and safety which demanded that prompt and adequate measures be taken to guard against it.

205. Id. at 224 . 
Thus far, I have taken an external view of Korematsu, contextualizing the case to expose the constraint inherent in the larger socioeconomic context in which it was decided. Yet equally revealing is the insight that comes from an internal view of the Justices' decisionmaking in the case. From the outside looking in, the Justices refused to strike down internment. From the inside looking out, it was clear they did not like what they saw.

Unlike the Justices in Plessy and Buck, who had no hesitation rejecting the rights claims at issue in those cases, the Justices in Korematsu were anguished. ${ }^{206}$ They no more wanted to validate Japanese American internment than to invalidate it, and so they did neither, ducking the constitutionality of internment altogether. This they accomplished by construing the military's exclusion order as merely an order not to be someplace-the West Coast theatre of operations-rather than as an order to be someplace else. ${ }^{207}$ In reality, the opposite was true. The military's exclusion order did not merely order exclusion; it effectuated exclusion by ordering Japanese Americans to report to designated assembly centers, where they were placed under guard and then moved to internment camps. ${ }^{208}$

The difference mattered. Under the majority's narrow construction of the case, Korematsu was not so different from Hirabayashi-indeed, that is what the Supreme Court's opinion said. ${ }^{209}$ To be sure, forcing Japanese Americans to leave an area was more extreme than enforcing a curfew, but both were of a completely different ilk than detaining Japanese Americans in internment camps for an indeterminate period of time. Validating internment was, from

206. For the saga of the Justices' decisionmaking in the case, see IRONS, supra note 158, at $320-41$.

207. See id. at 223 (“[W]e are dealing specifically with nothing but an exclusion order."); see also Gee, supra note 165, at 776 (noting that the Supreme Court in Korematsu managed to evade the most basic question-whether internment was constitutional).

208. The majority's opinion in Korematsu conceded as much. See Korematsu, 323 U.S. at 221 (noting that the military exclusion order stated that evacuation would be "effected by assembling together and placing under guard all those of Japanese ancestry at central points, designated as 'assembly centers' in order to insure the orderly evacuation and resettlement of Japanese ... ."); $i d$. at 223 ("Korematsu was under compulsion to leave the area not as he would choose, but via an Assembly Center."); see also IRONS, supra note 158, at 320 ("As worded, the exclusion orders themselves necessarily led to detention for some period of time in the relocation centers.").

209. See Korematsu, 323 U.S. at 219 ("It was because we could not reject the finding of the military authorities that it was impossible to bring about an immediate segregation of the disloyal from the loyal that we sustained the validity of the curfew order as applying to the whole group. In the instant case, temporary exclusion of the entire group was rested by the military on the same ground."); see also IRONS, supra note 158, at 322 (quoting Chief Justice Stone in conference as reasoning, "If you can do it for curfew you can do it for exclusion."). 
the start, something the Justices in Korematsu were simply not inclined to do. ${ }^{210}$

Yet even with the majority's exceedingly narrow construction of the case, the Justices struggled. The vote in Korematsu was six-tothree, but it began as five-to-four, and the vote of one of the five majority Justices, Justice Rutledge, was tentative. ${ }^{211}$ Justice Roberts dissented because he thought the issues of exclusion and internment were inseparable. ${ }^{212}$ Justice Jackson dissented because he thought the Supreme Court should neither enjoin the exclusion order nor assist in its enforcement. ${ }^{213}$ And Justice Murphy dissented because he thought the order was racist through and through. ${ }^{214}$ Justice Douglas almost dissented for the same reason as Justice Roberts-he thought the majority's attempt to separate exclusion from internment was untenable-but his view was that the threat of invasion justified both, so his position was more of a concurrence from the start. ${ }^{215}$

Chemerinsky claims that because three Justices dissented in Korematsu, others could have, and should have, voted to strike down the military's order too. But that puts more weight on the dissents than they can bear, and misses how far the majority in Korematsu stretched. Justice Jackson was not a vote to strike down internment; his position was limited to not lending the Supreme Court's imprimatur to its enforcement. ${ }^{216}$ Justice Roberts also wrote a qualified dissent, stating that if the exclusion order had been as the majority had claimed, he "might agree" with its disposition of the case. $^{217}$ Only Justice Murphy was strident in his view of the

210. See IRONS, supra note 158, at 320-23 (discussing Justices' intent from the start to narrowly construe the case and their subsequent struggle to do so).

211. See id. at 332-39 (discussing original vote in Korematsu); DiCKson, supra note 159, at 690 (quoting Justice Rutledge as stating in conference, "I had to swallow Hirabayashi. I didn't like it . . . . I vote to affirm tentatively."); Justice Rutledge's biographer claimed that the Japanese internment cases caused the Justice so much anguish that they were one of the problems "which pushed Wiley Rutledge along the path to his premature grave." ҮАмAMOTO ET AL., supra note 148, at 64 .

212. See Korematsu, 323 U.S. at 225-33 (Roberts, J., dissenting).

213. See id. at 242-48 (Jackson, J., dissenting).

214. See id. at 233-42 (Murphy, J., dissenting).

215. See IRONS, supra note 158, at 332-39 (discussing Justice Douglas's original vote and rationale, as well as his decision to switch sides, ultimately voting with the majority).

216. See Korematsu, 323 U.S. at 247-48 (Jackson, J., dissenting):

I should hold that a civil court cannot be made to enforce an order which violates constitutional limitations even if it is a reasonable exercise of military authority. . . . I do not suggest that the courts should have attempted to interfere with the Army in carrying out its task. But I do not think they may be asked to execute a military expedient that has no place in law under the Constitution.

217. See Korematsu, 323 U.S. at 231 (Roberts, J., dissenting) (arguing that the majority's artificially narrow construction of the exclusion order "is a substitution of a hypothetical case for 
unconstitutionality of the order based on race-but even his vote can carry only so much weight given his vote to uphold the military's racebased order in Hirabayashi the year before. ${ }^{218}$

In short, what is striking about Korematsu is not its dissents, but rather how far the Justices in the majority stretched to not uphold internment, knowing that they were not about to strike it down. The Justices in the majority did judicial backflips to avoid ruling on the issue; indeed, their strained analysis cost them one vote, almost cost them another, and made drafting the opinion in the case an exceedingly difficult and protracted task. ${ }^{219}$ Ironically, the case condemned for upholding Japanese American internment never actually ruled on it at all.

But what Korematsu did not do, its companion case of Ex parte Endo 220 did-at least in part. Endo was a habeas corpus petition that challenged the continued internment of a citizen who had subsequently passed the government's loyalty screening. As in Korematsu, the Justices refused to rule on the constitutionality of internment itself, but as to Endo-and the 70,000-some others like her still in internment camps ${ }^{221}$ - they had little problem resolving the case. For a unanimous Court, the Endo opinion stated:

We are of the view that Misueye Endo should be given her liberty. In reaching that conclusion, we do not come to the underlying constitutional issues which have been argued. For we conclude that, whatever power the War Relocation Authority may have to detain other classes of citizens, it has no authority to subject citizens who are concededly loyal to its leave procedure. ${ }^{222}$

the case actually before court" and adding "I might agree with the court's disposition of the hypothetical case.").

218. See Hirabayashi v. United States, 320 U.S. 81, 109-14 (1943) (Murphy, J., concurring). Interestingly, even Justice Murphy conceded that the fear of imminent invasion in early 1942 justified reasonable military means to counter the danger; he just disagreed that what the military did was reasonable. See Korematsu, 323 U.S. at 235 (Murphy, J., dissenting) ("It must be conceded that the military and naval situation in the spring of 1942 was such as to generate a very real fear of invasion of the Pacific Coast, accompanied by fears of sabotage and espionage in that area. The military command was therefore justified in adopting all reasonable means necessary to combat these dangers.")

219. See IRONS, supra note 158, at 325-41 (discussing Justices' struggle to write the opinion in Korematsu). The process was so difficult that at one point, dissenting Justice Murphy sent a note to his clerk stating, "The Court has blown up on the Jap case-just as I expected it would." Id. at 332 .

220. 323 U.S. 283 (1944).

221. See IRONS, supra note 158 , at 323 (noting that as defined, the narrow issue in Korematsu was important "only as a matter of legal debate" because removal had already occurred, but that the Court's resolution of Endo "would affect not only Mitsuye Endo but some 70,000 other Japanese Americans still confined in relocation centers").

222. Ex parte Endo, 323 U.S. at 297; see also IRONS, supra note 158, at 341-42 (noting that in drafting the opinion in Endo, Justice Douglas "matched Black in his determination to evade the question of detention"). 
The government barely put up a fight. ${ }^{223}$ Its justification for internment had been the inability to quickly determine Japanese American loyalty. Once that determination had been made, the justification for internment was gone.

Because the military's loyalty screening in the internment camps was nearly complete by the fall of 1944, Endo effectively ended internment. ${ }^{224}$ But it was not alone in doing so. Shortly after the November 1944 election (and well after the Justices' mid-October conference discussions and vote in Endo), the government decided to end internment too. ${ }^{225}$ The War Authority's announcement came December 17, 1944. ${ }^{226}$ The Supreme Court's announcement of Endo came the next day.

Just one more point remains to be made, and it concerns a late-and at the time gratuitous-addition to the Supreme Court's opinion in Korematsu. In the final draft of the Court's opinion, Justice Black added a paragraph stating that "all legal restrictions which curtail the civil rights of a single racial group are immediately suspect" and subject to "the most rigid scrutiny." 227 It was likely in response to Justice Murphy's stinging dissent, ${ }^{228}$ and was not loadbearing in the Court's analysis. Indeed, it was awkwardly placed in the midst of the Court's chronology of the case and then ignored for the remainder of the opinion. ${ }^{229}$ But it made a statement, and the statement stuck. Today, Korematsu is (ironically) the case to cite for the birth of the strict scrutiny standard of review for race classifications. ${ }^{230}$ Indeed, the NAACP in Brown $v$. Board of Education $^{231}$ cited Korematsu for the proposition that de jure

223. See IRONS, supra note 158, at 318-19, 342 (detailing portions of oral argument and noting that the government's "half-hearted defense" of internment in Endo, where loyalty had been determined, made the outcome "almost inevitable").

224. Those who failed the loyalty screening could be held on an individual basis, and those who passed (like Endo) had to be freed. See id. at 269.

225. See id. at 345 .

226. See id.

227. Korematsu v. United States, 323 U.S. 214, 216 (1944).

228. See id. at 242 (Murphy, J., dissenting) ("I dissent, therefore, from this legalization of racism.").

229. See id. at 216; see also IRONS, supra note 158, at 340 ("The odd placement of this paragraph in the opinion - stuck in the middle of the chronology of the case-suggests that Black inserted it at the last minute, more as window dressing than as a plank in the opinion's foundation.").

230. See Gee, supra note 165 , at 778 ; DiCKSON, supra note 159 , at 692 . For an argument that "the most rigid scrutiny" in Korematsu is not the same as strict scrutiny, at least as applied today, see Richard Fallon, Strict Judicial Scrutiny, 54 UCLA L. REV. 1267 (2007).

231. 347 U.S. 483 (1954) (invalidating de jure segregation in public schools). 
segregation required more than reasonableness review, as had been applied in Plessy. ${ }^{232}$

Today the internment of Japanese Americans during World War II is widely viewed as one of our nation's most regrettable mistakes. ${ }^{233}$ But in the wake of Pearl Harbor, when an attack on the West Coast was viewed as imminent, there were few dissenters. And there is little reason to think the Supreme Court could have played that role-even the dissenters in Korematsu unanimously approved Hirabayashi's race-based restriction in 1943. What is remarkable about Korematsu and its overlooked companion case of Endo is not what the Justices failed to do, but rather what they did. The Supreme Court was not about to tell the war-making branches that they could not do what they thought necessary for the common defense at the outbreak of war, but it refused to sanction the internment decision itself, freed those who remained interned even after their loyalty had been established, and planted the seeds for more exacting judicial review. In light of the rhetoric of failure that conventionally characterizes the case, it is striking just how sensitive to civil liberties the Supreme Court in Korematsu actually was.

Taken together, Plessy, Buck, and Korematsu paint a picture of the Supreme Court that differs dramatically from Chemerinsky's portrayal. The question then becomes what we can learn from these reconstructed narratives. To that question, and a story of Supreme Court success, the discussion turns next.

\section{What To MAKe of Three SuPREME COURT "FAILURES"}

Thus far, I have considered the historical context of Plessy, Buck, and Korematsu individually. In this Part, I turn to lessons learned from the cases when considered together. The first, and most obvious, is that historical context matters, although the point requires more nuance than might appear at first blush. I then turn from consideration of the point on a macro level to consideration of the

232. See DiCKSON, supra note 159, at 691-92 n.137 (explaining how the NAACP in Brown v. Board of Education argued that Korematsu "raised the bar for racial classifications" from reasonableness to strict scrutiny).

233. See Gee, supra note 165, at 786-87 (discussing the redress movement); Greenaway, supra note 171, at 190-91 (discussing Congressional apology and restitution in 1988, and quoting Earl Warren as saying, "I have since deeply regretted the removal order and my own testimony advocating it . . .."). We now know that there was conflicting evidence as to whether internment was necessary in the first place, but the government in Korematsu suppressed that information, altered reports, and literally burned earlier versions of those documents so the Supreme Court (and public) would never know. For a fascinating account, see IRONS, supra note 158 , at $186-218$. 
point on a micro level, using Plessy, Buck, and Korematsu to illustrate three ways that culture can constrain the Justices' proclivity to protect. I close with an examination of the premise that undergirds the rhetoric of failure, and locate its origin in the Supreme Court itself. In various ways, I argue, the very notion of Supreme Court "failures" reveals a larger, and largely untold, story of Supreme Court success.

\section{A. Historical Context Matters}

Chemerinsky's Case Against the Supreme Court is replete with the word "today."234 "I will focus especially on examples... where virtually everyone today-liberal and conservatives alike-can agree that the Court was wrong," Chemerinsky writes. ${ }^{235}$ And at least with regard to cases like Plessy, Buck, and Korematsu, he makes good on that promise. No one thinks of these cases as representing a morally acceptable outcome today-but the Supreme Court did not decide these cases today. The Court decided them in three completely different historical contexts, each with its own set of cultural constraints. Here, then, is the first (and most obvious) lesson that Plessy, Buck, and Korematsu teach: Historical context matters.

Chemerinsky concedes that the Justices live in society and are thus likely to reflect its values, ${ }^{236}$ but views this recognition as an all too easy excuse. ${ }^{237}$ "It is quite justifiable to have expected the Court to do better in all these areas," he writes. ${ }^{238}$ "The Supreme Court is there

234. See, e.g., ChEmerinsky, supra note 1, at 65 ("Without doubt, any court today would regard it as expression protected by the very core of the First Amendment."); id. at 111 ("Unlike the decisions from the 1890s to 1936, which have few defenders today . ..."); id. at 127 ("[N]o one today is likely to criticize the holding in Brown or the results in the other decisions declaring segregation unconstitutional. These cases dramatically changed society and are a powerful example of what the Court exists to accomplish."); $i d$. at 136 ("Today, these decisions applying the Bill of Rights to state and local governments seem unassailable and are hardly criticized."); $i d$. at 334 ("I do not expect that many today, even staunch conservatives, would defend the Supreme Court's decisions about slavery in the nineteenth century ....”).

235. Id. at 6 .

236. See id. at 293:

Simply put, why has the Supreme Court failed so often at times when it has been most needed? There is no single or easy answer to these questions. Of course, a part of the answer is that the justices live in society and thus are likely to reflect its attitudes and values at any point in time.

237. See id. at 89 ("It is too easy to make excuses for the justices and say that it is unrealistic to have expected them to do better.").

238. Id. at 337; see also id. at 60 ("We can and should expect more from the Court than what it has historically done to enforce the Constitution ...."). 
to enforce the limits of the Constitution, and the justices are given life tenure to help insulate them from majoritarian pressures." 239

But the majoritarian pressures at work in cases like Plessy, Buck, and Korematsu are not the kind that job security can offset. Life tenure cannot remove the Justices from the cultural context in which they operate. It cannot insulate them from values of the society in which they live. When the Justices decide cases, they do so against a backdrop of cultural norms that naturally inform their views of what is, and is not, proper in the realm of constitutional interpretation. To expect otherwise- to think that the Justices could somehow extricate themselves from the influence of their social environment-is to ask for more than they (or anyone else) can reasonably do.

Projecting today's values onto yesterday's Court is understandable - our judgments reflect the normative assumptions of our time, just as the Justices' judgments in Plessy, Buck and Korematsu reflected theirs-but it is hardly realistic or fair. If Booker T. Washington could not see the injustice of de jure segregation in the 1890 s, how can we possibly expect the Justices in Plessy to have done so? If Helen Keller could not see the depravity of forced sterilization in the 1920s, why would we expect the Justices to have seen it in Buck v. Bell? And if Earl Warren, the Japanese American Citizens League, and the ACLU could not see the moral bankruptcy of interning people based on race in World War II, what makes us think the Justices in Korematsu would have had that clarity? Hindsight is twenty-twenty, but when the Supreme Court decides cases, it does not have the luxury of that view.

The point has purchase not only for considering The Case Against the Supreme Court, but also for constitutional theory more broadly. Scholars have long lamented the disconnect between constitutional theory and practice, with political scientists particularly discouraged by the legal academy's failure to produce normative theories based on a realistic conception of judicial review. ${ }^{240}$ At the

239. Id. at 294; see also id. at 60 ("Supreme Court justices-and all federal judges-are given life tenure and protection from any decrease in salary precisely so they can be more independent and stand up to majoritarian pressures."); $i d$. at 89 ("[J]ustices have life tenure so they can be immune from political pressures, to enforce the limits of the Constitution."); id. at 308 ("Judicial independence means that a judge should feel free to decide cases according to his or her view of the law and not in response to popular pressure.").

240. See, e.g., Doni Gewirtzman, Glory Days: Popular Constitutionalism, Nostalgia, and the True Nature of Constitutional Culture, 93 GEO. L.J. 897, 903 (2005) (“[A]n accurate descriptive account of how our interpretive system functions has been all too absent from constitutional theory."); Mark A. Graber, The Nonmajoritarian Difficulty: Legislative Deference to the Judiciary, 7 Stud. Am. Pol. DEv. 35, 71 (1993) ("Theories of judicial review in a democracy will be of only limited interest until they correctly describe the circumstances in which judicial policymaking 
heart of that failure is a lack of appreciation of the cultural parameters within which the Supreme Court actually operates. The Supreme Court is no oracle. It cannot step outside its historical context to do what a Court at a later time might do. The tendency to view Supreme Court decisions ahistorically-to overlook the social, political, and ideological context in which the decisions were madegives rise to a distorted sense of the Court's countermajoritarian capacity, skewing our conception of judicial review. ${ }^{241}$

Plessy, Buck, and Korematsu are powerful illustrations of the point. Chemerinsky claims that the Supreme Court in each of these cases could have, and should have, done better, but only an ahistoric understanding of these cases supports that conclusion. In reality, the historical context in which each case was decided made it hard to imagine the Justices ruling the other way. This is not to deny that the Supreme Court has, at times, protected vulnerable minorities from majoritarian overreaching-but its most famous feats in that regard have involved majoritarian overreaching at the local level. ${ }^{242}$ When the problem is not a pocket of oppression but rather society itself, the same values that permeate the rest of the population are highly likely to color the Justices' views, limiting what the Supreme Court can realistically do.

This is not to say that historical context always, or even often, plays a determinative role in the Supreme Court's decisionmaking. Sometimes it does, a point I have endeavored to make with the case studies of Plessy, Buck, and Korematsu. But what is true of those cases may not be true of others. Historical context can constrain the Justices' proclivity to protect and thereby limit what the Supreme Court can realistically do, but within the realm of realistic

normally takes place."); Darren Lenard Hutchinson, The Majoritarian Difficulty: Affirmative Action, Sodomy, and Supreme Court Politics, 23 LAW \& INEQ. 1, 93 (2005) ("[L]egal theorists have neglected to utilize the rich analysis of public institutions that social scientists have produced. This omission limits the relevance of legal theory."); Terri Peretti, The Virtues of "Value Clarity" in Constitutional Decisionmaking, 55 OHIO ST. L.J. 1079, 1081 (1994) (arguing that current constitutional theory "rest[s] on a fundamental misunderstanding of how American politics actually operates"); Keith E. Whittington, Constitutional Theory and the Faces of Power, in THE JUDICIARY AND AMERICAN DEMOCRACY: ALEXANDER BICKEL, THE COUNTERMAJORITARIAN DifFiculty, AND CONTEMPORARY CONSTITUTIONAL ThEORY 163-64 (2005) ("Constitutional theory ... has ignored important aspects of how constitutionalism works in practice. The countermajoritarian framework is adequate neither for understanding how constitutional government works, nor for evaluating the exercise of judicial review.").

241. See Klarman, supra note 23, at 31 ("So long as we approach constitutional issues ahistorically, we will continue to exaggerate the countermajoritarian capacity of judicial review.").

242. See, e.g., Gideon v. Wainwright, 372 U.S. 335 (1963) (incorporating Sixth Amendment right to counsel); Brown v. Board of Education, 347 U.S. 483 (1954) (invalidating de jure school segregation). 
possibilities, a number of other factors influencing the Justices' decisionmaking are also in play.

Like law. In the case studies, I have noted the law when it appeared to exercise influence. In Plessy, for example, the law strongly supported the Justices' ruling. And in Buck, the collusive nature of the litigation produced weak constitutional claims, which impacted the legal context in which the Justices experienced the case. In Korematsu, by contrast, the law was not a prominent part of the story I told because it was capacious enough to accommodate a ruling either way (and indeed, the Justices' efforts to squeeze the facts of Korematsu into the doctrine of Hirabayashi provide a nice illustration of the point). That said, it is worth noting that not one of these Supreme Court "failures" was obviously wrong on the law. As Jamal Greene has observed, anticanonical cases are not anticanonical because of their legal analysis; they are anticanonical because they have rhetorical purchase in representing value judgments that we strongly reject today. ${ }^{243}$

The Justices' views about the role of the judiciary and institutional values like federalism and separation of powers also play a part in the mix. Chemerinsky may view the Supreme Court's raison d'être as the protection of vulnerable minorities, but the Justices may beg to differ and those differences matter. Institutional values like federalism and separation of powers likewise may cut against recognizing rights claims. Again, Plessy, Buck, and Korematsu are instructive. ${ }^{244}$ But as I have discussed elsewhere, these sorts of considerations tend to be porous enough to be a conduit of culture of their own. ${ }^{245}$ Where culture cuts against protection, the Justices are likely to be all the more wary about the prospect of overstepping their judicial bounds; and where culture cuts in its favor, the Justices are likely to be all the more convinced that protection in such circumstances is exactly what the judiciary is for. ${ }^{246}$

243. See Greene, supra note 11 , at $380-85$.

244. In Plessy and Buck, the police powers doctrine reflected an extremely limited conception of the judiciary's role vis-à-vis the legislature, and in Korematsu, the judiciary's limited role vis-à-vis the war-making branches of government during war drove the analysis in the case. In addition, various Justices, like Justice Frankfurter in Korematsu and Justice Holmes in Buck, were strong advocates of judicial restraint, which impacted their views (and votes) in a variety of doctrinal settings.

245. See Corinna Barrett Lain, Deciding Death, 57 Duke L.J. 1, 76-77 (2007).

246. For an excellent illustration of the point, see Michael J. Klarman, The Racial Origins of Modern Criminal Procedure, 99 MICH. L. REV. 48 (2000) (discussing the role of extralegal context in the Supreme Court's early criminal procedure decisions, which abandoned a century and a half of nonintervention in state criminal procedure based on federalism concerns). 
And then there is ideology. Chemerinsky spends a substantial amount of time on the Justices' ideological preferences in The Case Against the Supreme Court, and for good reason. Empirical research has shown that as the number of "GOP Justices" rises, the Supreme Court's support for rights claims falls-even in the face of supportive public opinion. ${ }^{247}$ For those who, like Chemerinsky, want the Court to support rights claims, such findings provide cause for concern. A 2009 study showed that four of the five most conservative Justices on the Supreme Court since 1937 were sitting on the Court at that time: Roberts, Scalia, Thomas, and Alito. ${ }^{248}$ Justice Ginsburg, the current Court's most liberal Justice, barely made the liberal top $10 .{ }^{249}$ To the extent the Supreme Court is a conservative Court, ideology will likewise limit the Court's proclivity to protect.

But appointing Supreme Court Justices who are more receptive to rights claims is no panacea. As Chemerinsky recognizes, Korematsu was written by Justice Black, "a great civil libertarian," and was supported by Justice Douglas, "one of the most liberal justices in American history." ${ }^{250}$ Likewise, Buck v. Bell was written by none other than Oliver Wendell Holmes, "one of the patron saints of modern civil liberties." 251 The problem in these cases is not that the Justices were unreceptive to rights claims. The problem is that their progressive views were constrained by the tenor of repressive times.

All this is to say that historical context is just one influence on the Justices' decisionmaking; many others are also in play. And those can cut in favor of protection or against it - or even both ways, with some considerations going one way and others going another. Historical context places intrinsic limits on the Supreme Court's protective proclivities, and that limits what the Court can realistically do-but within those limits, a number of considerations will factor into how the Court actually rules in any given case.

247. See Thomas R. Marshall \& Joseph Ignagni, Supreme Court and Public Support for Rights Claims, 78 JUdiCATURE 146, 149-51 (1994) (presenting findings of empirical study).

248. See Adam Liptak, To Nudge, Shift or Shove the Supreme Court Left, N.Y. TIMES (Jan. 31, 2009), http://www.nytimes.com/2009/02/01/weekinreview/01liptak.html?_r=0 [https://perma .cc/TS4K-T5Y6] (discussing the study). The study does not reflect Justice Scalia's death on February 13, 2016.

249. See id. ("But Justice Ginsburg, whom the study identifies as the most liberal current [J] ustice, barely makes the Top 10 in the full tally.").

250. Chemerinsky, supra note 1 , at 56.

251. See supra note 73 (discussing Holmes). 


\section{B. Three Ways that Culture Can Constrain the Supreme Court's Proclivity to Protect}

Thus far, I have argued that historical context matters by considering its importance at the macro level. In this Section, I make the point in more granular fashion by considering its importance at the micro level, examining how the constraint of culture actually manifests itself. Here again, Plessy, Buck, and Korematsu are instructive, illustrating three ways that culture can constrain the Justices' proclivity to protect.

First, culture creates an outer boundary of normative possibilities in any given case, at least for the Supreme Court as a whole. Steven Winter comes close to articulating the point in recognizing that "judges cannot even think without implicating the dominant normative assumptions that shape their society." 252 Their normative judgments are embedded in a larger cultural construct, and the parameters of that construct have implications for the realm of realistic possibilities in any given case at any given moment in time. As Lawrence Friedman explains:

In some ways, people are like animals born and raised in zoos; they are not aware that their world of cages and enclosures is highly artificial, that their range of behavior is limited by conditions they did not create for themselves.... This is true for legal behavior as much as for any other form of behavior. ${ }^{253}$

Culture itself sets limits on the plausible constitutional outcomes that a majority of the Justices might find agreeable. Those limits are somewhat capacious and very much subconscious, but they are real.

Plessy v. Ferguson is a nice illustration of the point. In 1896, the egalitarianism embodied in Brown v. Board of Education was simply not within the Supreme Court's culturally defined realm of possibilities, Justice Harlan's dissent notwithstanding. In any society, there will be some with seemingly radical views. The question is what was realistically possible for the Court as a whole given the context I have reconstructed, and the egalitarianism of an era fifty years later is simply not on that list.

Second, culture can constrain the Justices' proclivity to protect through the gravitational pull of public opinion. Supreme Court Justices are members of society, and as such, are naturally influenced

252. Steven L. Winter, An Upside/Down View of the Countermajoritarian Difficulty, 69 Tex. L. REV. 1881, 1925 (1991).

253. Lawrence M. Friedman, Coming of Age: Law and Society Enters an Exclusive Club, 1 ANN. REV. L. Soc. SCI. 1, 10 (2005). 
by the same events that shape the rest of the public's views. As Chief Justice Rehnquist explained thirty years ago:

The judges of any court of last resort, such as the Supreme Court of the United States, work in an insulated atmosphere in their courthouse where they sit on the bench hearing oral arguments or sit in their chambers writing opinions. But these same judges go home at night and read the newspapers or watch the evening news.... Judges, so long as they are relatively normal human beings, can no more escape being influenced by public opinion in the long run than can people working at other jobs. ${ }^{254}$

Echoing the point, Justice Douglas wrote, "The Court is not isolated from life. Its members are very much a part of the community and know the fears, anxieties, cravings and wishes of their neighbors." 255 Whether the Justices' views are shaped by what others think, or by the underlying events that shape what others think, the result is the same. In the aggregate, the Justices are unlikely to stray far from dominant public opinion because they are members of the public too. ${ }^{256}$

Buck v. Bell is the quintessential illustration of the point. It is striking how popular eugenics was in the first two decades of the twentieth century. The feel of the historical record is that everyone who was anyone supported it (and everyone else too). In that sort of atmosphere, it is almost unfathomable that the Justices would have invalidated eugenic sterilization-not because they lacked the courage or might, but because it is hard to imagine them not being part of the dominant view.

Third, strong gusts of public passion can constrain the Supreme Court's proclivity to protect. The trauma of a major event like Pearl Harbor or 9/11 creates an urgency, a quickening of public opinion with little discussion and even less dissent. The threat of imminent invasion is perhaps the best example, but any highly salient event that grips the nation with fear or ignites public passion will create the sort of high-stakes scenario that typically leads the Court to

254. William H. Rehnquist, Constitutional Law and Public Opinion, 20 SuffolK U. L. Rev. 751,768 (1986).

255. Justices Douglas continued, stating, "That does not mean that community attitudes are necessarily translated by mysterious osmosis into new judicial doctrine. It does mean that the state of public opinion will often make the Court cautious when it should be bold." YAMAMOTO ET AL., supra note 148, at 164 (quoting Justice Douglas).

256. This is less true on an individual basis. When considered individually, empirical research has shown that the Supreme Court's moderate, swing Justices are substantially more responsive to public opinion than those at the ideological extremes, although on a more or less ideologically balanced Supreme Court, even an effect on one of the Justices may be enough to render the Court responsive as a whole. See William Mishler \& Reginald S. Sheehan, Public Opinion, the Attitudinal Model, and Supreme Court Decision Making: A Micro-Analytic Perspective, 58 J. POL. 169, 189-93 (1996) (presenting empirical data). 
defer rather than protect. ${ }^{257}$ In such scenarios, the Justices are no less susceptible to the intensity of the moment than anyone else, so this is just as one might expect. 258

Korematsu is the classic case to illustrate the point. Looking back at the historical context in which it was decided, Justice Douglas later wrote:

Our Navy was sunk at Pearl Harbor and no one knew where the Japanese fleet was. We were advised on oral argument that if the Japanese landed troops on our west coast, nothing could stop them west of the Rockies. The military judgment was that, to aid in the prospective defense of the west coast, the enclaves of Americans of Japanese ancestry should be moved inland... The decisions were extreme and went to the verge of wartime power; and they have been severely criticized. It is, however, easy in retrospect to denounce what was done, as there actually was no attempted Japanese invasion of our country. .. But those making plans for defense of the nation had no such knowledge and were planning for the worst. ${ }^{259}$

Again, the problem was not that Justice Douglas was insensitive to civil liberties claims. It was that the sensibilities he brought to the bench were constrained by a particularly urgent, salient event. It is hard to imagine the Supreme Court opposing the military, president, Congress, and the American public in the throes of war. As Mike Klarman has recognized, "No court in American history has been that countermajoritarian." 260

Plessy, Buck, and Korematsu illustrate three ways that culture can constrain the Justices' proclivity to protect, but this is not meant to suggest that they provide a complete list. Noticeably absent from the discussion has been the constraint that the Justices experience when they worry about the repercussions of their rulings-concerns about enforcement, the Supreme Court's legitimacy, and the possibility of retaliation are prime examples. As I have discussed elsewhere, culture impacts these sorts of concerns too, exacerbating them when the context is hostile to rights claims and ameliorating them when it is supportive. ${ }^{261}$ But as Plessy, Buck, and Korematsu show, culture typically limits what the Justices want to do before it

257. For an insightful discussion of the Supreme Court's tendency to defer to the political branches in "high stakes" cases, see Eric Berger, Deference Determinations and Stealth Constitutional Decision Making, 98 IowA L. REV. 465, 515-17 (2013). To some extent, all three cases illustrate a variation of this dynamic. In Plessy, the driver was a spike in race-related violence against African Americans. In Buck, it was fear that the country would be swamped with incompetence. And in Korematsu, it was the fear of imminent invasion.

258. See supra note 13 (quoting Benjamin Cardozo's observation that "[t]he great tides and currents which engulf the rest of men do not turn aside in their course and pass the judges by.")

259. DeFunis v. Odegaard, 416 U.S. 312, 339 n.20 (1974) (Douglas, J., dissenting).

260. Michael J. Klarman, Brown, Originalism, and Constitutional Theory: A Response to Professor McConnell, 81 VA. L. REV. 1881, 1933 (1995).

261. See Lain, supra note 245 , at 74 . 
limits what they can. ${ }^{262}$ Society is not monolithic, but where its currents are particularly strong (as was true in all three cases), they will impact the Justices' thinking just like they impact everyone else. Plessy, Buck, and Korematsu illustrate three different manifestations of the implicit constraint that culture imposes, but other manifestations and more conscious, explicit forms of constraint are possibilities too.

\section{A Story of Supreme Court Success}

Thus far, I have argued that historical context can constrain the Justices' proclivity to protect, limiting what the Supreme Court can reasonably be expected to do. I have also suggested that within the rhetoric of failure lies a story of Supreme Court success. Here is the gist: the rhetoric of failure that marks cases like Plessy, Buck, and Korematsu assumes that the Supreme Court can and should play a heroic, countermajoritarian role. But that role is neither obvious nor predetermined; we think the Court should play it primarily because the Court has told us this is true. With the Court as author of the very expectations by which it is judged a failure, the fact of Chemerinsky's disappointment in the Court is itself evidence of a larger narrative's success. And the point is more than academic. However historically inaccurate, the Court's self-ascribed role as a countermajoritarian hero has had practical consequences too, setting in motion forces that can, over time, actually ease the Court's cultural constraints and inspire its protection.

To examine the claim more closely, consider first the central premise upon which Chemerinsky's Case Against the Supreme Court is based. Chemerinsky confidently claims that "the two preeminent purposes of the Court are to protect the rights of minorities who cannot rely on the political process and to uphold the Constitution in the face of repressive desires of political majorities." ${ }^{263}$ In making this claim, Chemerinsky is not alone. Over the past fifty years, the protection of minority rights from majoritarian overreaching has emerged as a primary-perhaps the primary-justification for judicial

262. See Robert G. McCloskey, The American Supreme CourT 209 (2d ed. 1994) ("We might come closer to the truth if we said that the judges have often agreed with the main current of public sentiment because they were themselves part of that current, and not because they feared to disagree with it.").

263. CHEMERINSKY, supra note 1, at 298. 
review. ${ }^{264}$ But where does one get this view of the Supreme Court's role? What is the basis for that claim?

Not the Constitution itself-at least not without a much thicker account of constitutionalism than what its text provides. Constitutional text imposes limits on democratic governance, but enforcing those limits does not invariably lead to a heroic, countermajoritarian conception of judicial review. As Mike Klarman has shown, the Constitution supports at least ten theories of constitutionalism, each with a corresponding justification for judicial review. ${ }^{265}$ Protection of minority rights is one of those theories, but it is one conception of the Court's role among many. To argue that the Constitution itself establishes the Supreme Court's preeminent purpose as being the protection of vulnerable minorities is a difficult claim to make; if not for the Supreme Court incorporating the Bill of Rights protections to the states, not even those protections would be a prominent part of the Court's enforcement role. ${ }^{266}$

One might respond by noting that the Framers were concerned with the protection of minority rights, and that much is true. ${ }^{267}$ Yet even this recognition does not provide an anchor for Chemerinsky's claim. The minority rights that the Framers were mostly concerned about-that of property owners, merchants, slave holders, and the like 268 - are not the kind that Chemerinsky has in mind. Indeed, the

264. See Marshall \& Ignagni, supra note 247, at 151 ("By far, the most commonly cited argument for this [Supreme Court] institution is that it helps protect controversial or unpopular minorities' civil liberties and rights.”). In 2008, Rebecca Zietlow did a Lexis search for law reviews written in the previous twenty years that advocated the position that the Supreme Court should protect minorities against the will of the majority, finding over 500 articles. See Rebecca E. Zietlow, The Judicial Restraint of the Warren Court (and Why it Matters), 69 OHIO ST. L.J. 255, 259 n.13 (2008). For a sampling of these works, see, e.g., Michael J. Perry, Protecting Human Rights in a Democracy: What Role for the Courts?, 38 WAKe FoREST L. REV. 635 (2003); Jeremy Waldron, A Rights-Based Critique of Constitutional Rights, 13 OXFORD J. LEG. STUD. 18 (1993).

265. See generally Michael J. Klarman, What's So Great About Constitutionalsim? 93 Nw. U. L. REV. 145 (1998) (articulating ten leading accounts of constitutionalism).

266. At the very least, this is true in the criminal context, where over ninety-five percent of all cases are tried at the state level. If the protections of the Fourth, Fifth, and Sixth Amendments had not been incorporated to the states, they would scarcely matter at all.

267. For example, Madison argued of a need to "protect the people against the transient impressions into which they themselves might be led" due to "fickleness and passion" or "sudden impulses . . . to commit injustice on the minority." JAMES MADISON, NOTES OF DEBATES IN THE FEDERAL CONVENTION OF 1787 193-94 (Adrienne Koch ed., 1996).

268. See id. at 77:

Debtors have defrauded their creditors. The landed interest has borne hard on the mercantile interest. The Holders of one species of property have thrown a disproportion of taxes on the holders of another species. The lesson we are to draw from the whole is that where a majority are united by a common sentiment, and have an opportunity, the rights of the minor party become insecure. 
Supreme Court's protection of the minority rights of property holders in cases like Dred Scott and Lochner forms a substantial part of Chemerinsky's complaint. ${ }^{269}$

Maybe the answer is nothing but need. As Barry Friedman has observed, we have a "need to imagine a countermajoritarian court, even if one $d[o e s]$ not exist." 270 This is what Mike Klarman calls the "psychological imperative" of a heroic, countermajoritarian Supreme Court, ${ }^{271}$ and Chemerinsky illustrates it beautifully when he asks, "If not the Court, then who will protect our most basic liberties and prevent people from suffering greatly from their infringements?" 272 Somebody has to be there to protect us from ourselves. ${ }^{273}$ If not the Supreme Court, who?

I don't pretend to have an answer to this question; maybe we do view the Supreme Court as playing a heroic, countermajoritarian role in part because we need to-but there is a better origin story yet, and its author is the Supreme Court itself. Why do we believe that the Supreme Court can protect vulnerable minorities and check the desires of repressive majorities? Because the Court has told us it is true.

The story starts in $1937 .{ }^{274}$ The "switch in time that saved nine" had ended the Lochner era; the Supreme Court capitulated on economic regulation, presuming its validity under the newly embraced

(emphasis added); see also KeRMit HALL, JUdicIAL REVIEW AND JUdICIAL POWER IN THE SUPREME COURT 283 (2013) ("[T]he framers viewed unchecked popular government as a threat to the rights of minorities, especially property owners, merchants, investors, and slaveholders."); Klarman, supra note 265, at 162 ("For much of its history, the Court protected the minority group for which the Framers entertained the greatest sympathy-property owners.").

269. See CHEMERINSKY, supra note 1, at 21-29 (discussing Dred Scott decision), 90-119 (discussing Lochner era decisions).

270. Barry Friedman, The Birth of an Academic Obsession: The History of the Countermajoritarian Difficulty, Part Five, 112 YALE L.J. 153, 161 (2002).

271. See Klarman, supra note 23, at 23-24 (recognizing point).

272. CHEMERINSKY, supra note 1 , at 60 .

273. See Sherry, supra note 10, at 1 ("Too much of a good thing can be bad, and democracy is no exception.").

274. This is not to deny that the Supreme Court recognized rights claims before then, although the cases typically cited for the point rested more on the protection of property rights and economic opportunity than on the protection of vulnerable minorities per se. See, e.g., Meyer v. Nebraska, 262 U.S. 390, 400 (1923) ("Plaintiff in error taught in school as part of his occupation. His right thus to teach and the right of the parent to engage him so to instruct their children, we think, are within the liberty of the Amendment."); Pierce v. Society of Sisters, 268 U.S. 510, 535 (1925) ("[Plaintiffs] have business and property for which they claim protection. These are threatened with destruction through the unwarranted compulsion which appellants are exercising over present and prospective patrons of their schools. And this court has gone very far to protect against loss threatened by such action.”). 
rational basis test. ${ }^{275}$ But that gave the Court an identity crisis as it struggled to find a sphere to reassert the legitimacy of judicial review. ${ }^{276}$ The result was history's most famous footnote-Carolene Products' footnote four-wherein the Court suggested that "more searching judicial inquiry" may be appropriate where legislation infringed on fundamental rights, interfered with the function of the political process, or concerned "discrete and insular minorities." 277 The constitutional revolution of 1937 had brought a constitutional revelation in 1938, and with it, the seeds of a heroic, countermajoritarian conception of judicial review.

And so it began. With a reference to "tyrannical governments" and World War II clearly on its mind, the Supreme Court in 1940 would claim that "courts stand against any winds that blow as havens of refuge for those who might otherwise suffer because they are helpless, weak, outnumbered, or because they are non-conforming victims of prejudice and public excitement." ${ }^{278}$ And in 1943, it followed with the claim that "the very purpose of a bill of rights was to withdraw certain subjects from the vicissitudes of political controversy, to place them beyond the reach of majorities and officials and to establish them as legal principles to be applied by the courts." 279 Never mind that footnote four was just an idea the Court was floating, a thought it hoped would spawn discussion and an agreeable realm for judicial review down the road. ${ }^{280}$ And never mind

275. See West Coast Hotel Co. v. Parrish, 300 U.S. 379, 391 (1937) (upholding constitutionality of minimum wage legislation, ending the Lochner era).

276. See Bruce A. Ackerman, Beyond Carolene Products, 98 HARV. L. Rev. 713, 714 (1985) (discussing Supreme Court's need to reassert its independence and reestablish the legitimacy of judicial review after capitulating on economic regulation); Kurt Lash, The Constitutional Convention of 1937: The Original Meaning of the New Jurisprudential Deal, 70 FordHAM L. REV. 459, 462 ("From the perspective of the Supreme Court, the New Deal Revolution was not about embracing Rooseveltian Progressivism, it was about reestablishing the legitimacy of judicial review in the modern world.").

277. United States v. Carolene Prods. Co., 304 U.S. 144, 152, n.4 (1938); see also CARL BRENT Swisher, The Supreme CourT IN MODERN Role 175 (1958) (recognizing that the role of the Supreme Court to protect civil liberties had "its formal start in a footnote to a case decided in 1938 ").

278. Chambers v. Florida, 309 U.S. 227, 236, 241 (1940).

279. West Virginia State Bd. of Educ. v. Barnette, 319 U.S. 624, 638 (1943).

280. As an exposé by Justice Stone's law clerk at the time explained:

The Footnote was being offered not as a settled theorem of government or Courtapproved standard of judicial review, but as a starting point for debate-in the spirit of inquiry, the spirit of the Enlightenment. . . The modest hope was that the Footnote would catalyze thoroughgoing analysis and discussion by bar, bench, and academe, and that a complete and well-rounded doctrine would eventuate.

Louis Lusky, Footnote Redux: A Carolene Products Reminiscence, 82 CoLUM. L. REV. 1093, 109899 (1982). 
that in the early years, these proclamations were more talk than action. $^{281}$ The Supreme Court said it was its role to play the countermajoritarian hero, and we have taken that as true.

But our conception of the Supreme Court in this regard is based not only on the Court's assertions. Chemerinsky's chapter entitled "What About the Warren Court?" is a nod to the rest of the story. ${ }^{282}$ The Warren Court is "the paradigmatic example of courts protecting the rights of minorities," Rebecca Zietlow observes, "a heroic icon for an entire generation of lawyers and academics, and many of their subsequent students." ${ }^{283}$ By conventional wisdom, the Warren Court played the heroic, countermajoritarian role time and time again. And if the Warren Court could do it, so the argument goes, the Supreme Court can do it at other times too.

Two observations about the Warren Court's role in this story merit mention. First, the popular conception of the Supreme Court as a staunch protector of minority rights is, as Zietlow notes, "a relatively recent phenomenon"--before the mid-1950s and 1960s, the Court was better known for denying rights claims than granting them. ${ }^{284}$ Second, and more fundamentally, not even the Warren Court actually exemplifies the heroic, countermajoritarian ideal for which it is famous. The Court did protect minority rights, but its protection was a reflection of, and response to, larger sociopolitical change. ${ }^{285}$ That said, neither of these points negates the fact that the Warren Court brought a tectonic shift in the Court's persona. Internalizing the language from an earlier era, the Warren Court forged a new image of judicial review.

And it stuck. In footnote four and related flourishes, in the Warren Court, even in Korematsu-the Court created an image, an

281. See Minersville Sch. Dist. v. Gobitis, 310 U.S. 586 (1940) (upholding flag salute statute against claim of religious liberty for Jehovah's witnesses); Korematsu v. United States, 323 U.S. 214 (1944) (upholding removal of Japanese citizens from homes during World War II); see also Lusky, supra note 280, at 1103 (noting that it was seventeen years after Carolene Products before the Supreme Court actually accepted its premise); Friedman, supra note 270, at 177 ("The range of liberties cases was not vast, however, largely because most of the rights in the Bill of Rights still were not applied against the states.").

282. ChEMERINSKY, supra note 1, at 120; see also id. at 13 ("I applaud the Warren Court and in many ways see it as a model for what the Court can be.").

283. Zietlow, supra note 264 , at $255,270$.

284. See id. at 262.

285. See generally L.A. Scot Powe, The WarRen Court AND American Politics (2000); Corinna Barrett Lain, Countermajoritarian Hero or Zero? Rethinking the Warren Court's Role in the Criminal Procedure Revolution, 152 U. PENN. L. REV. 1361 (2004); see also Mark Graber, Constitutional Politics and Constitutional Theory: A Misunderstood and Neglected Relationship, 27 LAW AND SOC. INEQ. 309, 313 (2002) (lamenting the fact that the legal academy has "analyzed Warren Court decisions as if Barry Goldwater had won the 1964 national election.”). 
expectation, a standard by which it would be judged. And that brings me back to The Case Against the Supreme Court.

Chemerinsky is disappointed in the Supreme Court for not fulfilling its role as protector of vulnerable minorities. But that role is not inherent in the Court's composition; it did not spring forth from the Constitution fully formed. It did not have to be, but it is, and it is because the Court created it. One answer to Chemerinsky, then, is that the Supreme Court may not live up to its heroic, countermajoritarian role, but that role would not exist but for the Court in the first place-and the very fact of Chemerinsky's disappointment is a reflection of how successful that role creation has been.

If the story ended there, the point would be purely academican interesting aside about the irony in Chemerinsky's disappointment with the Supreme Court. But the story does not end there. As it turns out, the expectations that the Court has created have had repercussions of their own.

One such repercussion is on the Supreme Court itself. The Court's self-conception of its role as a countermajoritarian protector has helped it stretch to its countermajoritarian limits, at least in certain contexts. Here, several of the Supreme Court's First Amendment cases come to mind; its protection of flag burning, cross burning, and Klu Klux Klan rallies as freedom of expression are prime examples. ${ }^{286}$ The conduct is extremely unpopular, and so one might think given the discussion thus far that the Justices would have little to no inclination to protect it. But the just opposite is true. The Court protects, and the public accepts-perhaps even supports-that protection in part because both the Justices and the public believe that protecting unpopular speech is what the Supreme Court is supposed to do. ${ }^{287}$ As Chemerinsky has recognized elsewhere, role recognition can have significant behavioral effects on the Supreme Court. ${ }^{288}$ The free speech context is one example. Although much work still needs to be done on why the Justices embrace their countermajoritarian role in some contexts and not others, one can at

286. See, e.g., Virginia v. Black, 538 U.S. 343 (2003) (protecting cross burning as free speech); Brandenburg v. Ohio, 395 U.S. 444 (1969) (protecting a KKK rally as free speech); Texas v. Johnson, 491 U.S. 397 (1989) (protecting flag burning as free speech).

287. See Or Bassok and Yoav Dotan, Solving the Countermajoritarian Difficulty? 11 InT'L J. CONST. L. 13, 24 (2013) ("Yet we argue that the public and its representatives want a Court that is willing to exercise its judicial review authority in a [countermajoritarian] fashion.").

288. See Erwin Chemerinsky, In Defense of Judicial Review: A Reply to Professor Kramer, 92 CALIF. L. REV. 1013, 1024 (2004) (recognizing point and noting that "[h]ow judicial review is discussed by scholars today will influence how it is practiced tomorrow.”). 
least say this: the conception of the Court as a countermajoritarian protector gives it more room and inclination to play that role than if that conception did not exist.

What I have just discussed is essentially bootstrapping-the Supreme Court's self-conception as a countermajoritarian protector creating the room and inclination to actually play it out-but equally, if not more significant has been the impact of the Court's role on others. In creating expectations, the Court created a cadre of believers, social activists who have faith in the Court's ability to play a heroic, countermajoritarian role. Chemerinsky is one of them. And believers do not stop believing when the Court lets them down, they do not stop litigating just because they lose. They search and search until they find the winning narratives, which change the framing of the issues, which creates empathy for outsiders, which starts conversations, which brings attention to an issue, which builds momentum for change. And over time, when there is enough momentum for change, those boundaries imperceptibly, but surely, move. In short, the Justices cannot transcend their cultural constraints, but the expectations the Court has created can do something better-they can set in motion the very forces that can, over time, ease those constraints and inspire the Court's protection.

Even our disappointment in the Supreme Court for failing to live up to our expectations plays an important part in this process. What do we do as a result of that disappointment? We talk about it. We blog about it. We write op-eds and law review articles about it. And if we get mad enough, and are knowledgeable and dedicated enough, we even write books about it. ${ }^{289}$ And those start conversations of their own (like this one).

This is not to say that the story I have told is a bed of roses; no interesting story ever is. Frustration mounts when the Supreme Court fails to meet our expectations time and again, eroding the Court's support. ${ }^{290}$ And the closer the Court comes to actually playing a heroic, countermajoritarian role, the more it risks triggering a

289. See CHEMERINSKY, supra note 1.

290. Chemerinsky's book is a testament to the frustration of the faithful, and arguably the Supreme Court's low public approval ratings are a reflection of this phenomenon as well. See Justin McCarthy, Disapproval of Supreme Court Edges to New High, GaLluP (Oct. 2, 2015), http://www.gallup.com/poll/185972/disapproval-supreme-court-edges-new-high.aspx

[https://perma.cc/7PJP-MBS9] (reporting the results of a 2015 Gallup poll showing that 50\% of respondents disapproved of the job the Supreme Court was doing, while $45 \%$ approved, and noting that the disapproval rating was a new high). 
backlash that will hurt the very cause it is trying to help. ${ }^{291}$ Moreover, the Court's robust recognition of rights claims can cut for, and against, the liberal agenda-again, the free speech context is instructive. ${ }^{292}$ And last but not least, none of what I have discussed can take back the decades of suffering from the legal sanction of racism under 'separate but equal,' or the thousands who were forcibly sterilized in the wake of Buck v. Bell, or the Supreme Court's approval of over 100,000 Japanese Americans ripped from their homes during World War II.

But this story and its consequences do present a curious upside to the ahistoric view of the Supreme Court that results in decisions like Plessy, Buck, and Korematsu being portrayed as failures, rather than regrettable mistakes reflective of regrettable times. The Supreme Court cannot live up to Chemerinsky's expectations. But in numerous ways, the fact that he even has those expectations is itself stunning evidence of a vastly underappreciated, and decidedly consequential, story of Supreme Court success.

\section{CONCLUSION}

Prolific author and respected civil rights litigator Erwin Chemerinsky has high expectations of the Supreme Court and is understandably disappointed by decisions like Plessy, Buck, and Korematsu. But his disappointment reflects an ahistoric view of what the Supreme Court can realistically do. This is not to say that viewing the Court ahistorically is all bad. However historically inaccurate, the Supreme Court's image as a countermajoritarian savior ready and able to transcend its cultural constraints has set in motion forces that can, over time, ease those constraints and inspire the Court's protection. Given the Justices' inherent limitations, that is no small measure of success.

291. The paradigmatic example is Furman v. Georgia, 408 U.S. 238 (1972), which invalidated the death penalty as it was then administered. See Lain, Furman Fundamentals, supra note 15.

292. See, e.g., Citizens United v. Fed. Election Comm'n, 558 U.S. 310 (2010) (holding that the First Amendment protects the speech of corporations and that campaign contributions constitute a constitutionally protected form of free speech). 